\title{
REVIEW
}

\section{Spawning stock, egg production and larval survival in relation to small pelagic fish recruitment}

\author{
Stylianos Somarakis*, Stavroula Tsoukali, Marianna Giannoulaki, \\ Eudoxia Schismenou, Nikolaos Nikolioudakis
}

Hellenic Centre for Marine Research (HCMR), Institute of Marine Biological Resources and Inland Waters (IMBRIW), Thalassocosmos Gournes, Heraklion, Crete, Greece

\begin{abstract}
Under the general framework of existing recruitment hypotheses, knowledge on the drivers and mechanisms involved in the determination of the year class strength of small pelagic fish (SPF) is briefly reviewed with focus on selected aspects of the adult and larval stages, related to breeding patterns, egg production, spawning habitats, reproductive potential and early life survival. An analysis of stock-recruitment time series data is carried out, showing that the maximum recruitment capacity of clupeoid stocks increases with the strength of temporal autocorrelation in recruitment $(R)$ and decreases as the coefficient of variation of $R$ becomes larger. Reproductive strategy in combination with the thermal and trophic conditions of the ecosystem and the life cycle pattern of the stock can influence the relative importance of high and low frequency variability in recruitment that combine to generate the population fluctuations of SPF. Selective fishing can reduce the reproductive potential and alter the spawning phenology of the stocks. To understand the ways by which the distribution, abundance and survival of larval stages are influenced by trophodynamic and physical factors, it is important to recognize all those milestones in fish ontogeny associated with significant changes in capabilities and behavior (e.g. onset of schooling). Temperature affects many parameters related to egg production and early life survival, but the relative importance of such temperature effects is expected to differ substantially in contrasting SPF habitats.
\end{abstract}

KEY WORDS: Small pelagic fish - Recruitment - Stock-recruit relationships - Capital-income breeding $\cdot$ Stock reproductive potential $\cdot$ Larval growth and survival

\section{INTRODUCTION}

Starting with the seminal work of Johan Hjort in the early 20th century, interest in the mechanisms underlying recruitment variability has always been strong because the limited understanding of population fluctuations restricts our ability to make reliable management predictions (e.g. Punt et al. 2014). Moreover, there have been several recent observations that fishing increases population variability (Hsieh et al. 2006, Anderson et al. 2008), and there is

${ }^{*}$ Corresponding author: somarak@hcmr.gr

${ }^{\S}$ Advance View was available online July 17, 2018 further concern that the drivers of variability may be shifting due to a changing climate (Rijnsdorp et al. 2009, Pörtner \& Peck 2010).

Year class strength has generally been considered to be primarily determined by the survival during the early life stages (reviewed in Houde 2009). Spawning stock is generally a poor predictor of recruitment strength (e.g. Cury et al. 2014); however, it is unrealistic to assume that there is no relationship between spawning stock and subsequent recruitment (Hilborn et al. 2017). It is also impossible to fully

() The authors 2019. Open Access under Creative Commons by Attribution Licence. Use, distribution and reproduction are unrestricted. Authors and original publication must be credited. 
appreciate the drivers of recruitment variability without also considering other characteristics of the adult population, such as the annual fecundity, spawning habitat and timing of reproduction. Stock reproductive potential (the number of eggs produced and their quality, Trippel 1999) is the initial step in the recruitment process but has received little attention so far in small pelagic fish research, especially in anchovies and sardines (Ganias et al. 2014). Energy acquisition and allocation to reproduction and the pattern of oocyte recruitment and maturation regulate the number of eggs produced each year (McBride et al. 2015). However, the fate of these eggs strongly depends on spatiotemporal spawning patterns that determine the initial conditions for egg and larval dispersal and the match/mismatch between larval and planktonic production (Sinclair 1988, Cushing 1990). Finally, fishing can reduce the reproductive potential of the stocks (Marshall 2009) and alter the adult spawning patterns (e.g. timing of spawning; Wright \& Trippel 2009).

In this article, we deal with aspects related to the spawning stock, egg production and early life survival of small pelagic fish (SPF), aspects that we consider important for explaining their recruitment fluctuations, based on our experience and research on anchovy and sardine stocks in the Mediterranean Sea. We do not intend to present a thorough review of the topic, but to provide some new insights mainly from comparisons between stocks and species residing in different ecosystems, such as small SPF stocks in the oligotrophic and warm Mediterranean Sea and large stocks in eutrophic and colder habitats.

The paper is organized as follows. We begin with the presentation of main findings from an analysis of stock-recruit data available for clupeoid stocks (details of data and analysis are given in the Supplement at www.int-res.com/articles/suppl/m617p113 _supp.pdf). The aim of analyzing these data was to provide an assessment of differences in patterns of

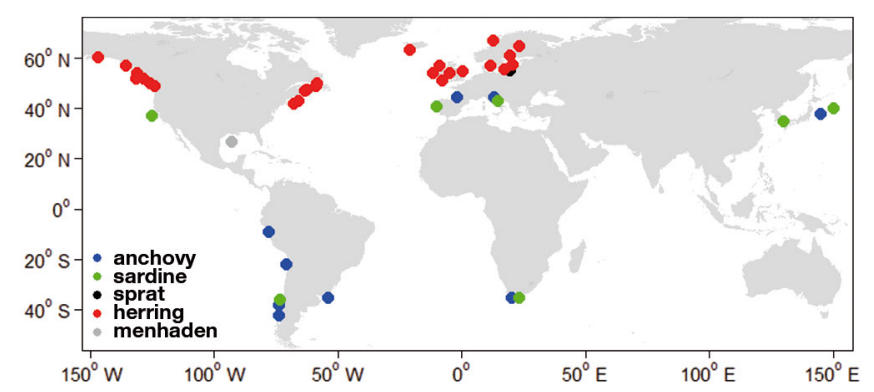

Fig. 1. Distribution of the stocks considered in the study of stock-recruit relationships of clupeoid stocks recruitment fluctuations among SPF stocks, species, and ecosystems. The stock-recruit topic is followed by a review and synthesis of selected aspects of the adult and larval stages related to breeding patterns, egg production, spawning habitats and stock reproductive potential, as well as density-dependent processes and potential fishing impacts. Under the framework of existing recruitment hypotheses, we discuss growth and survival during the larval stage with emphasis on important ontogenetic thresholds. Finally, temperature effects on fecundity and larval survival are summarized with the aim to highlight the relative importance of these effects in different SPF species and ecosystems.

\section{THE SPAWNER-RECRUIT RELATIONSHIP}

We first examined the stock-recruit relationships of clupeoid stocks (see the Supplement) to see if any useful information about recruitment fluctuations could be extracted from existing stock assessment data. We used all available and reasonably long spawning stock (SSB) and recruitment $(R)$ time series ( $\mathrm{n}=43$ ), mainly from the RAM legacy stock assessment database (Ricard et al. 2012) (Fig. 1, see Table S1 in the Supplement). The SSB, $R$ and, when available, the fishing mortality $(F)$ time series were standardized to unit variance to facilitate comparisons among stocks and ecosystems, and subsequently the Ricker model (Ricker 1975) was fitted to the normalized $R$ and SSB data of each stock (see Fig. S1 in the Supplement). We restricted comparisons to stocks with significant Ricker parameters $(a$ or $b$, the density-independent and the densitydependent coefficient respectively) and with no obvious structure in model residuals (indicating nonstationary stock-recruit relationship) (Tables S2 \& S3, Fig. S2 in the Supplement).

The aim of the analysis was to answer the following questions: (1) How variable is recruitment in different SPF stocks, species, and ecosystems? (2) Is recruitment temporally autocorrelated? (3) Does the level of fishing mortality affect the relationship between spawning stock and recruitment? (4) Are the observed patterns of variability and temporal autocorrelation related to the recruitment potential of the stocks?

Examples of Ricker model fits are presented in Fig. 2. Most stocks, e.g. the Scotian shelf herring, exhibited high variability about the Ricker curve whereas in stocks like the Peruvian anchoveta the model had a closer fit but the density-dependent 

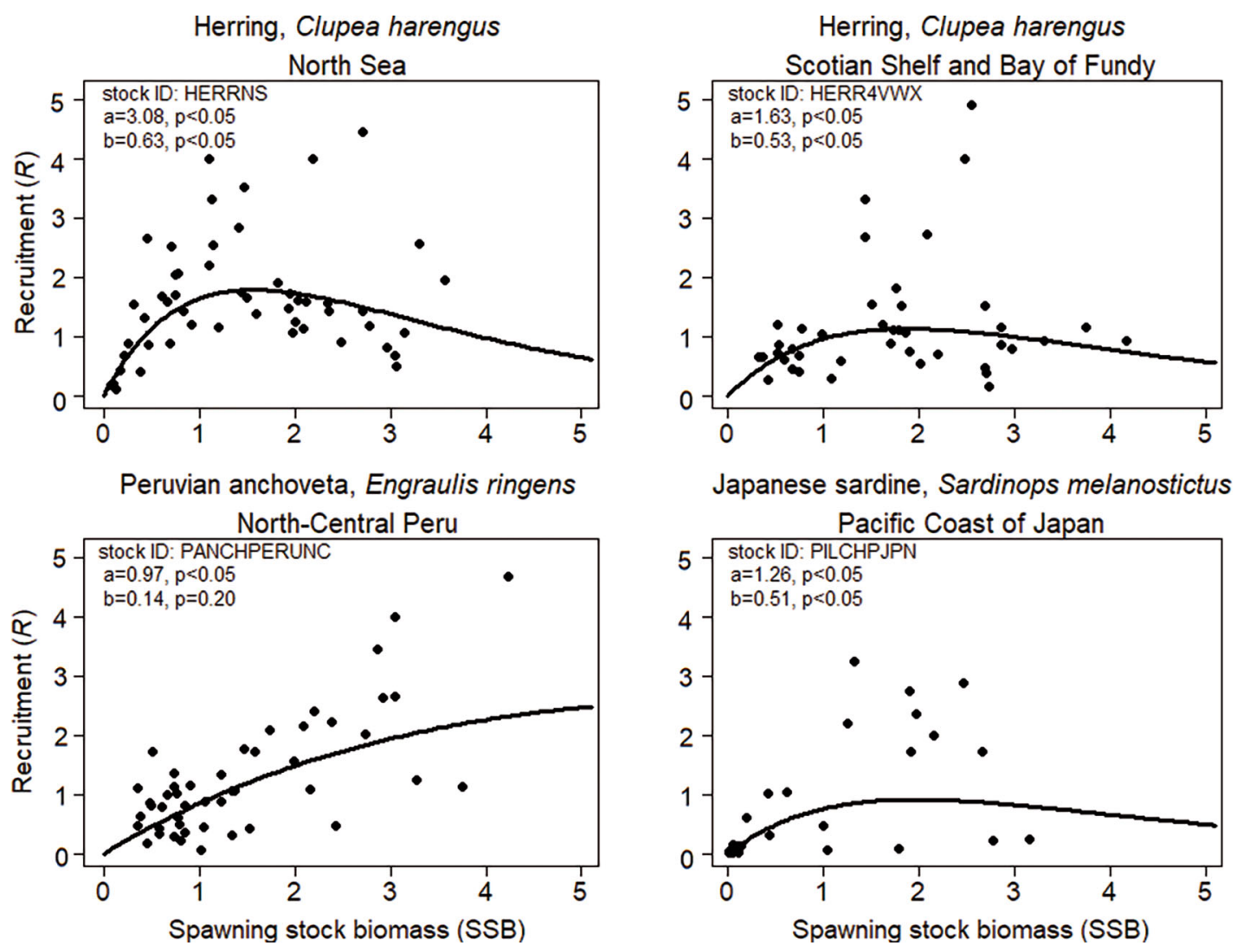

Fig. 2. Examples of Ricker model fits for selected clupeoid stocks

parameter (b) was not statistically significant (Fig. 2). Most interestingly, the strength of autocorrelation in recruitment varied widely among stocks (Fig. 3; see Table S4, Fig. S3 in the Supplement), ranging from no significant autocorrelation to moderate or high autocorrelation (e.g. Japanese sardine, Fig. 3). Finally, the first order autocorrelation in recruitment was significantly and positively correlated with the squared correlation between the observed and the predicted values of the stockrecruit relationship ( $\mathrm{r}=0.863, \mathrm{p}<0.001)$, implying that high temporal autocorrelation was associated with a stronger Ricker fit.

The strength of recruitment autocorrelation has received increased attention in recent years: Assuming no serious bias in the stock assessment data (e.g. ageing errors [Ricard et al. 2016] or other influential assumptions of the different stock assessment approaches [Dickey-Collas et al. 2015]), high temporal autocorrelation in recruitment is considered to indicate that $R$ is governed by low frequency variability, imposed by the environmental forcing, i.e. the long-term changes in temperature, food or predator abundance (Pyper \& Peterman 1998, Pepin 2016, Ricard et al. 2016).
Clupeoids in upwelling and non-upwelling areas as well as herrings of the NE Atlantic had on average lower coefficients of density dependence and higher autocorrelation in $R$ compared to herrings in the NW Atlantic and NE Pacific (Fig. 4). Most American herring stocks did not exhibit significant autocorrelation in $R$, hence, recruitment in American herrings seems to be dominated by high frequency (interannual) variability.

The density-dependent coefficient (b) was negatively correlated with average fishing mortality (Fig. 5) implying that stocks harvested with high fishing rates exhibit weaker density dependence. The correlation was mainly due to herrings of the NE Pacific and NW Atlantic which have been fished at lower average rates compared to e.g. the European herring stocks.

Recently, Britten et al. (2016) introduced the use of maximum recruitment capacity $\left(R_{\mathrm{MAX}}\right)$, as a measure of stock productivity at the recruitment stage:

$$
R_{\mathrm{MAX}}=\frac{a}{b} \mathrm{e}^{-1}
$$

$R_{\mathrm{MAX}}$ is a biomass-independent measure of maximum recruitment and does not depend on current 

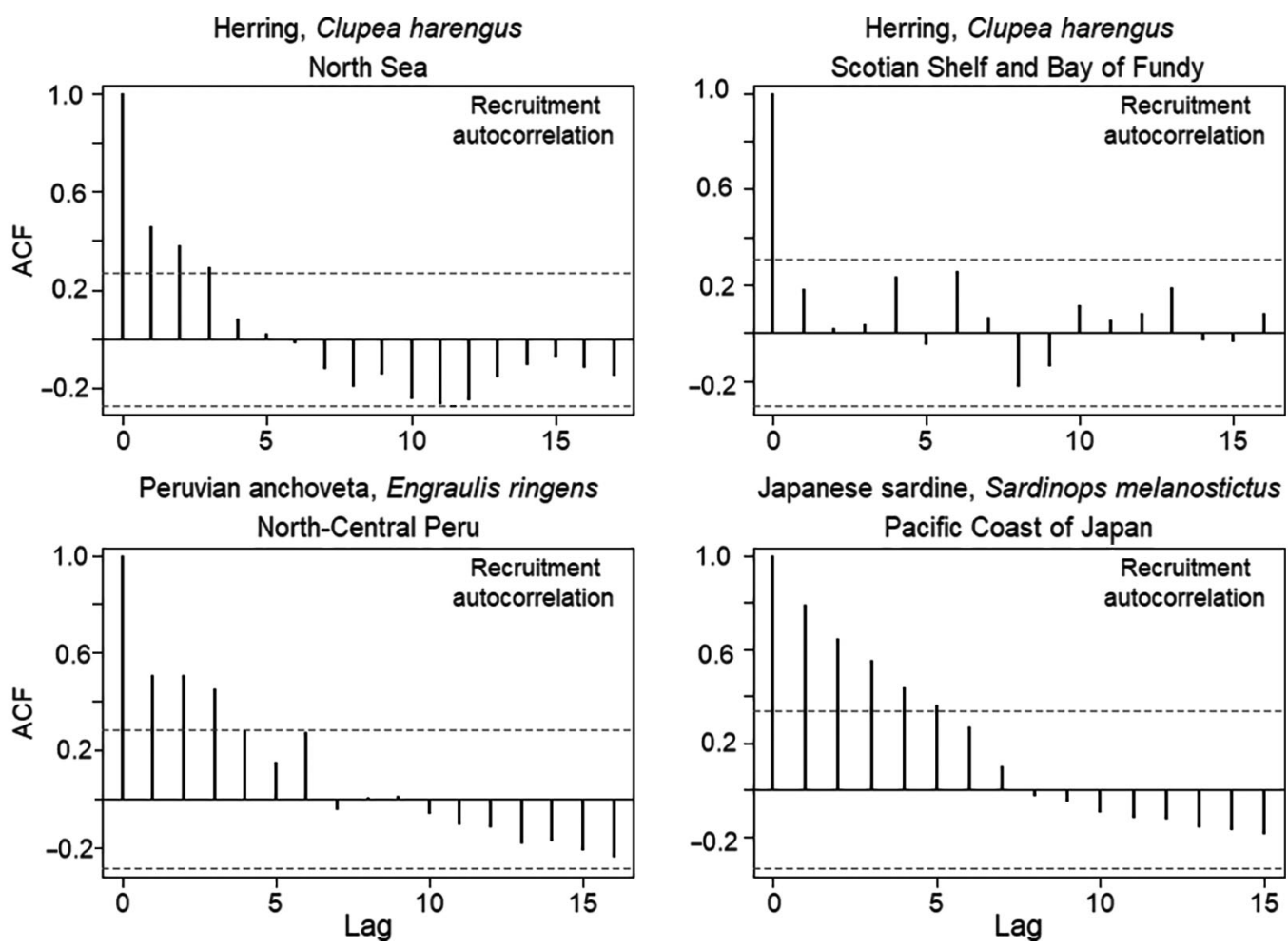

Fig. 3. Autocorrelation plots for the recruitment time series of the selected clupeoid stocks of Fig. 2. The horizontal dashed lines indicate the 0.5 significance level

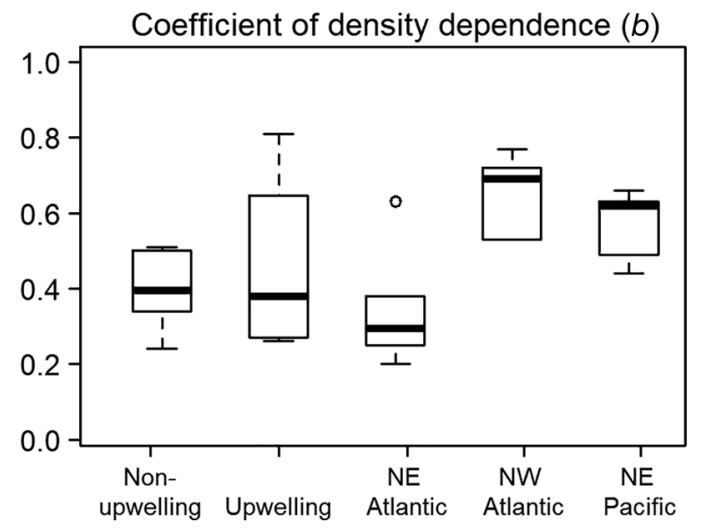

First order autocorrelation in $R$

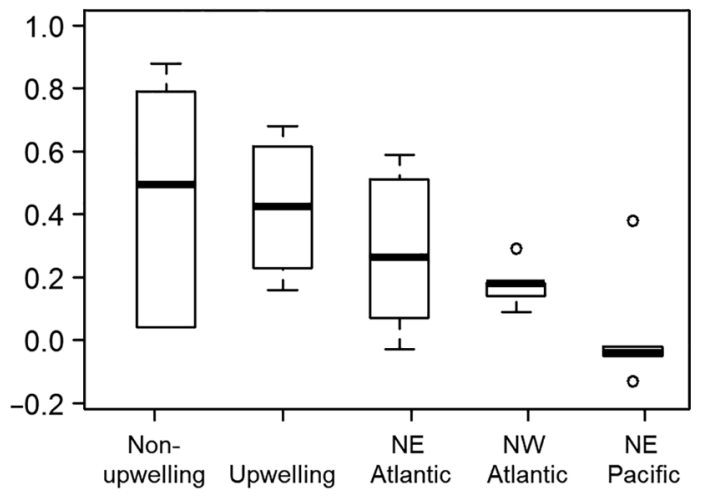

stock size, allowing comparison of both abundant and heavily depleted stocks. It is nevertheless highly correlated with alternative biomass-dependent measures of recruitment success (Britten et al. 2016). For the clupeoid stocks considered in our analysis (see Table S5 in the Supplement), $R_{\mathrm{MAX}}$ was negatively related with the coefficient of variation $(\mathrm{CV}(R))$ and positively related with autocorrelation in $R$ (Fig. 6). In other words, recruitment capacity of clupeoid stocks decreases with recruitment variability (mainly interannual variability, see the Supplement) and increases when $R$ is more tidily linked to the environmental forcing (which leads to the increase of temporal autocorrelation).

We argue here, and will provide some examples in the subsequent sections, that the relative importance of high and low frequency variability can be affected

Fig. 4. Box-and-whisker plots for the coefficient of density dependence $(b)$ of the fitted Ricker curves (upper panel) and the autocorrelation in recruitment (lower panel). The groups 'NE Atlantic', 'NW Atlantic' and 'NE Pacific' refer to herring (Clupea) stocks whereas the groups 'Non-upwelling' and 'Upwelling' refer to anchovy, sardine, sprat and menhaden stocks. Boxes indicate median and interquartile ranges. Whiskers delineate full ranges 


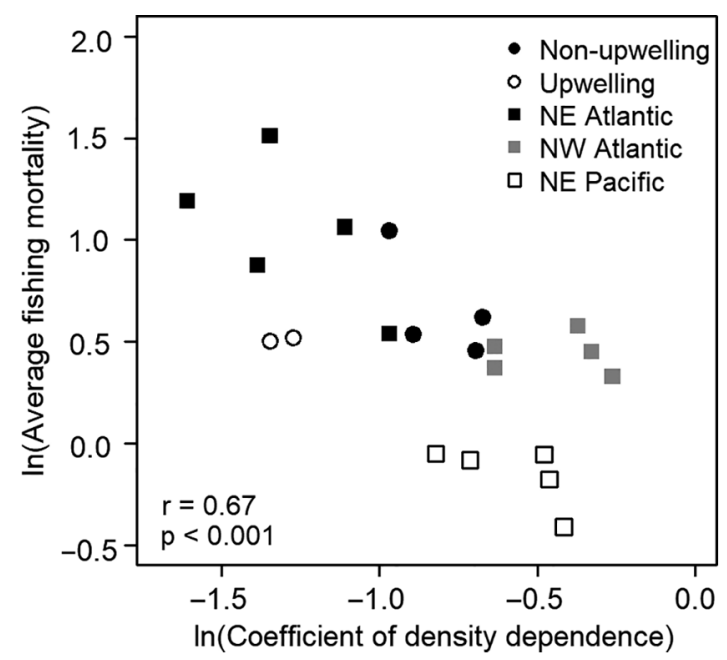

Fig. 5. Correlation between average fishing mortality and the coefficient of density dependence $(b)$ of the fitted Ricker curves. The groups 'NE Atlantic', 'NW Atlantic' and 'NE Pacific' refer to herring (Clupea) stocks whereas the groups 'Non-upwelling' and 'Upwelling' refer to anchovy, sardine, sprat and menhaden stocks

by the adult reproductive strategy and spawning pattern in combination with the prevailing physical and trophodynamic conditions of the ecosystem. For example, autocorrelation in $R$ will most likely be high when the adult spawning strategy ensures the close association of energy acquisition (feeding) with the production of eggs, so that the latter will happen in periods and areas of high planktonic productivity. Additionally, adult spawning within a physical domain that enhances planktonic retention is likely to decrease the stochasticity (interannual variability) in recruitment. Summer spawning of Mediterranean anchovy is a characteristic example of such a strat-

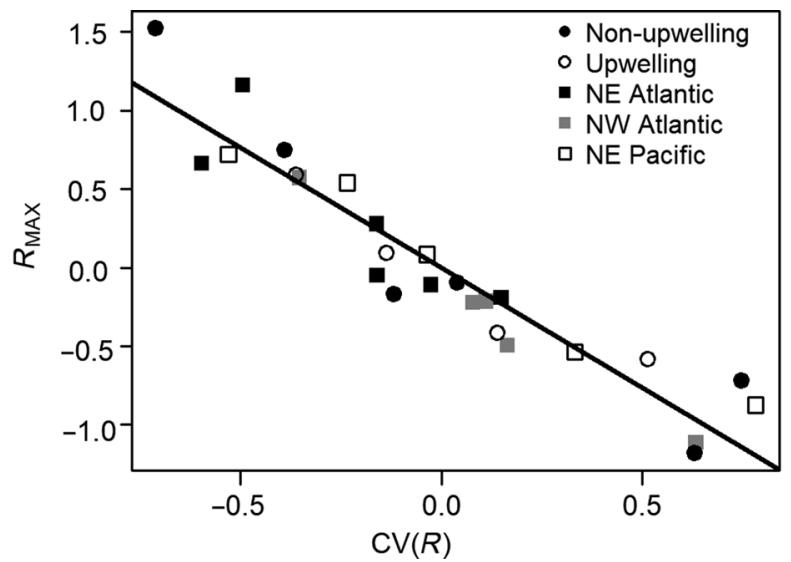

egy/spawning pattern, which, nevertheless, can lead to density-dependent larval mortality (see the next section). On the other hand, the uncertainty (high interannual variability) in recruitment increases with dispersal distance (Petitgas et al. 2013). Dispersal distance and advection 'accidents' will be increased when, for example, an oceanic current is used to entrain the eggs and larvae from the spawning sites to a distant nursery ground (see 'Spatial spawning patterns in relation to egg and larval advection'), or in the case of low temperatures, experienced by boreal species like herrings, that result in prolonged stage durations (see 'Temperature effects'). However, as suggested by Economou (1991), increased dispersal may be 'an insurance against density dependence'.

\section{REPRODUCTIVE STRATEGIES AND EGG PRODUCTION}

Fish need to acquire energy to reproduce (reviewed in McBride et al. 2015). Some species spawn and feed in separate areas, during different seasons, by storing energy and using it later for reproduction (i.e. capital breeding). Other species spawn using energy acquired locally, throughout a prolonged spawning season, allocating energy directly to reproduction (i.e. income breeding). Capital breeding allows feeding and spawning grounds to become disassociated in time and the cues that stimulate egg production are independent of the environmental conditions that the eggs and larvae will ultimately experience. In contrast, income breeding allows for a closer spatial and temporal association between

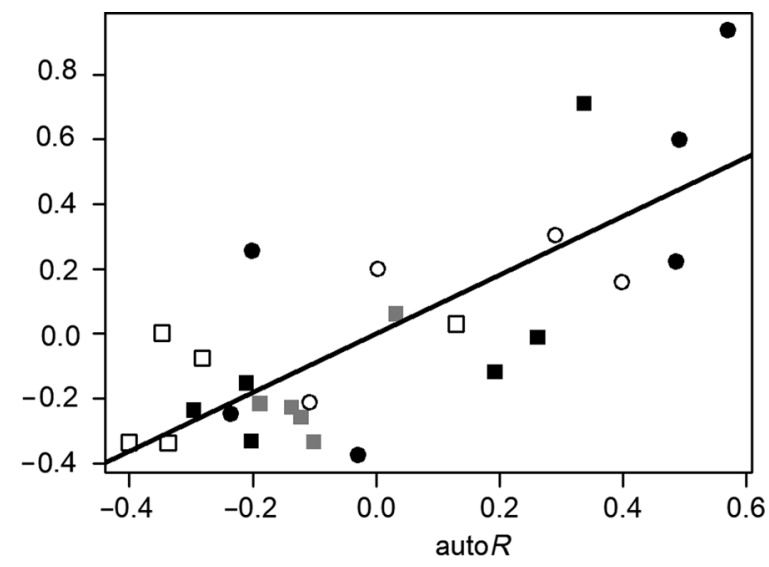

Fig. 6. Added-variable plots showing the partial effect of the coefficient of variation $(\mathrm{CV}(R))$ and the first order autocorrelation in $R$ (auto $R$ ) on the maximum recruitment capacity $\left(R_{\mathrm{MAX}}\right)$. Different symbols indicate species groups. The groups 'NE Atlantic', 'NW Atlantic' and 'NE Pacific' refer to herring (Clupea) stocks whereas the groups 'Non-upwelling' and 'Upwelling' refer to anchovy, sardine, sprat and menhaden stocks 
energy acquisition (feeding) and its use for spawning. It facilitates rapid transfer of ecosystem productivity to reproduction and the cues that inform the adults about their environment may relate directly to egg production and the environment their propagules will experience.

The patterns of energy acquisition and allocation to egg production and the dynamics of oocyte recruitment and spawning differ among the clupeoid species. Herrings are total spawners that ovulate and spawn demersal eggs in a single wave and skip spawning in some years. They are extreme capital breeders (McBride et al. 2015). Fecundity of both Atlantic herring (Ma et al. 1998) and Pacific herring (Hay \& Brett 1988) is known to vary due to nutritional condition of the spawning fish, and its annual variation is related to differences in food intake (Bowers \& Holliday 1961, Hempel 1971). Herring stocks have remarkably precise spatial and temporal spawning windows and invest a lot of energy to produce large eggs (e.g. Santos Schmidt et al. 2017).

Anchovies, sardines, sardinellas and sprats are batch spawners that ovulate and spawn (relatively small) pelagic eggs in discrete intervals over a relatively prolonged spawning season. They are indeterminate spawners, meaning that a significant portion of the annual fecundity is recruited during the current spawning season (de novo vitellogenesis) (Schismenou et al. 2012).

Multiple spawning clupeoids range from capital to extreme income breeders (Ganias et al. 2014, McBride et al. 2015). Capital-income breeding is a conditional strategy for many species whereby an individual's genotype is capable of moving along the capital-income continuum in response to its own physiological condition and the environment (McBride et al. 2015).

An example of a species which is more close to the capital breeding mode is the European sardine Sardina pilchardus (Fig. 7). In the eastern Mediterranean, sardine spawns in the winter months using the energy stored during the summer growing period (Ganias et al. 2007, 2014). Typically, there is a strong negative relationship between the mean monthly ovarian condition and the corresponding somatic condition (Fig. 7). However, besides capitalized energy, European sardine may also use current income to support egg production (Ganias 2009).

There is now evidence from several sardine stocks that a good somatic condition (accumulation of fat) during the period prior to spawning contributes to good recruitment. A significant positive correlation between Fulton's condition factor or lipid content and recruitment success was found for the Californian and Japanese sardines (Sardinops sagax, Zwolinski \& Demer 2012; S. melanostictus, Kawasaki \& Omori 1995) and the Iberian sardine (Sardina pilchardus, Rosa et al. 2010). To predict recruitment, Zwolinski \& Demer (2014) proposed a 'dual-phase' stock-recruitment model for the Californian sardine based on seasonal PDO-based (Pacific Decadal Oscillation) indices and a condition factor. Their model implied that summer feeding seasons favoring a good prespawning adult condition contribute significantly and positively to recruitment.

In species that are more close to the income breeding mode, like the European anchovy Engraulis encrasicolus in the eastern Mediterranean (Fig. 7), egg production is mainly fueled by direct food intake (Somarakis et al. 2004, Somarakis 2005). This species spawns during the summer months (Fig. 7) with ovarian and somatic condition both increasing inside the spawning period. In this case, monthly ovarian condition is positively correlated with hepatic condition rather than inversely related to somatic condition as in sardine (Fig. 7). Liver condition is, among others, an index of recent food intake (see discussion in Somarakis et al. 2012). However, besides direct food intake, energy gained and stored before the start of the spawning period might also affect reproductive output in this species (Basilone et al. 2006) and the relative batch fecundity has been shown to be positively correlated with somatic condition (Somarakis et al. 2012). Recently, Gatti et al. (2017) calibrated a bioenergetics model for European anchovy and sardine in the Bay of Biscay and showed that European anchovy is characterized by higher metabolic rates and requirements. This species benefits from periods of high food availability to carry out growth, spawning and reserve storage. Sardines have less demanding food requirements and metabolic costs and take advantage of their larger energy storage capacity to decouple spawning from increased prey availability thus displaying a more capital breeding mode.

The income breeding strategy (the close association of foraging, growth and spawning) is reasonable for multiple spawning clupeoids inhabiting warmer waters because of the high energetic cost of frequent spawnings and the fact that areas suitable for planktivorous adults are also suitable for the planktivorous larvae (Blaxter \& Hunter 1982). Peebles et al. (1996) showed that the egg and subsequent larval production of the bay anchovy, Anchoa mitchilli, is related to prey availability for both adults and larvae. They suggested that hatching larvae are likely to be associated with elevated nauplius densities because of 

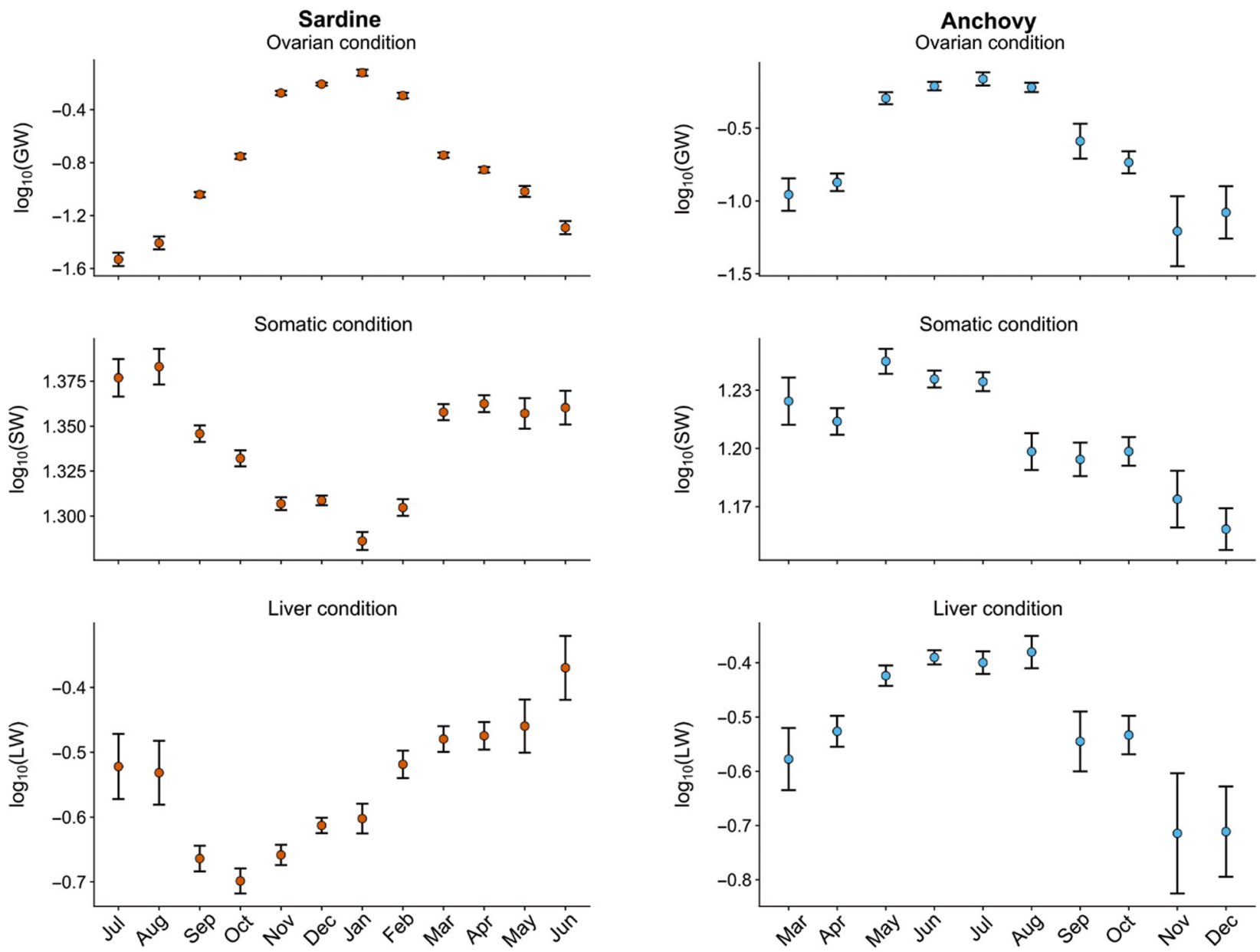

Fig. 7. Size-adjusted monthly means ( $\pm 95 \%$ confidence intervals) of ovary weight, somatic weight and liver weight for sardine Sardina pilchardus (data from Ganias et al. 2007) and anchovy Engraulis encrasicolus (S. Somarakis unpubl. data) in the Saronikos Gulf (Aegean Sea, eastern Mediterranean). A general linear model approach (described in Somarakis et al. 2012) was used to estimate size-adjusted means (somatic and organ condition)

the inherent interdependence between copepod life stages.

When food availability is not a limiting factor, the rate of vitellogenesis and the frequency of spawning are temperature-dependent (Takasuka et al. 2005, Ganias et al. 2014). For example, in boreal herrings the development of the single annual clutch may take almost a year (e.g. Santos Schmidt et al. 2017), whereas in tropical clupeoids the spawning interval is 1 to $3 \mathrm{~d}$ at peak spawning (e.g. Clarke 1987, Wright 1992, Milton et al. 1994, 1995). In the summerspawning European anchovy, the inter-spawning interval is typically 2 to $4 \mathrm{~d}$ (Schismenou et al. 2012, Uriarte et al. 2012) whereas in the winter-spawning sardines, 9 to $11 \mathrm{~d}$ (Ganias et al. 2014). In general, the spawning frequency is lower in upwelling areas or in winter-spawning species than in summerspawning anchovies (Fig. 8). The spawning fre- quency is consistently high for anchovy in the Bay of Biscay (Uriarte et al. 2012) during its spring to summer spawning period when surface temperatures are increased and mesozooplankton is abundant over a large spatial extent (e.g. Irigoien et al. 2007). In the oligotrophic Mediterranean, temperatures during the anchovy spawning period are high, but food availability is low and heterogeneous resulting in increased but highly variable spawning fractions (Fig. 8; Somarakis et al. 2004, 2012, Somarakis 2005). In the highly productive upwelling systems, temperature is relatively low $\left(14\right.$ to $\left.15^{\circ} \mathrm{C}\right)$ and seems to limit egg production through its effect on the rate of vitellogenesis and, consequently, the inter-spawning interval. In the oligotrophic Mediterranean, food availability can limit egg production mainly through its negative effect on spawning fractions (Somarakis et al. 2012). 


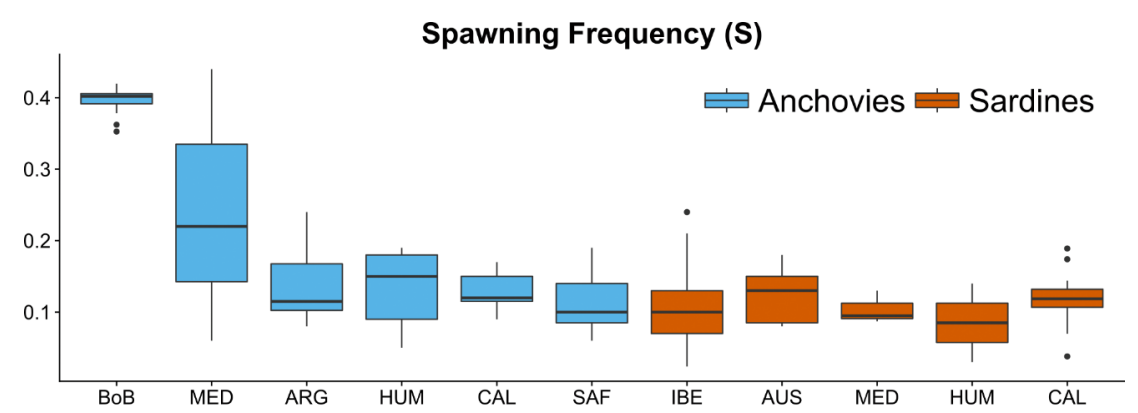

Fig. 8. Box-plots of spawning frequency (S: number of mature females spawning each night) estimated during the peak of the spawning season from 139 daily egg production method (DEPM) surveys reviewed in Ganias et al. (2014). BoB: Bay of Biscay - Engraulis encrasicolus: Uriarte et al. (2012). MED: Mediterranean Sea - E. encrasicolus: Somarakis et al. (2004, 2012), Melià et al. (2012); Sardina pilchardus: Casavola et al. (1998), Somarakis et al. (2006a). ARG: Argentine Sea - E. anchoita: Pájaro et al. (2009). HUM: Humboldt Current - E. ringens: Hunter \& Lo (1997), Braun et al. (2004), Cubillos et al. (2007); Strangomera benticki: Cubillos et al. (2007). CAL: Californian Current-E. mordax: Picquelle \& Stauffer (1985), Bindman (1986), Cotero-Altamirano \& Green-Ruiz (1997); Sardinops sagax: Macewicz et al. (1996), Lo et al. (1996, 2005, 2010). SAF: South Africa - E. encrasicolus: Shelton et al. (1993). IBE: Iberia - S. pilchardus: Garcia et al. (1992), Pérez et al. (1992), Cunha et al. (1992), Lago de Lanzós et al. (1998), ICES (1998), Quintanilla \& Pérez (2000). AUS: Australia — S. sagax: Fletcher et al. (1996),

Ward et al. (2001). Boxes indicate median and interquartile ranges. Whiskers delineate full ranges
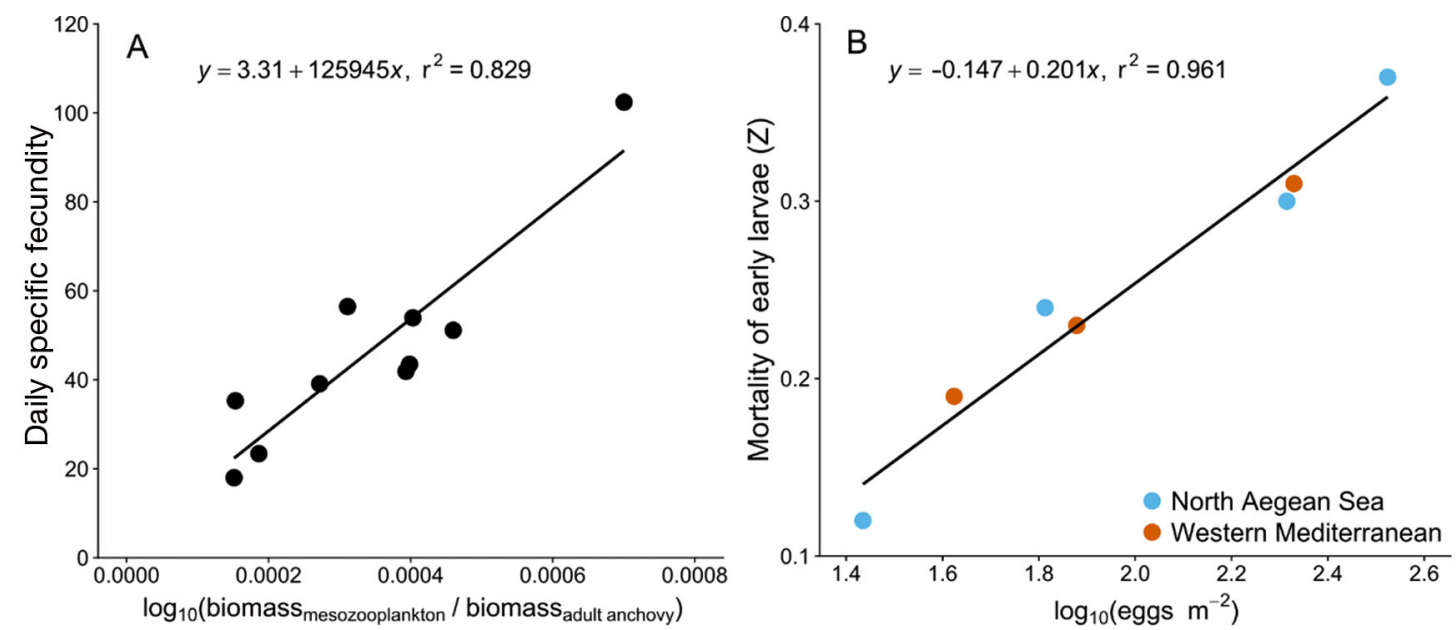

Fig. 9. Relationship (A) between daily specific fecundity of anchovy Engraulis encrasicolus (number of eggs produced daily per gram of the spawning stock) and the ratio of mesozooplankton biomass to adult biomass (redrawn from Somarakis et al. 2012), (B) between anchovy larval mortality and the abundance of anchovy eggs in the plankton (redrawn from Somarakis \& Nikolioudakis 2007)

Indeed, in the Aegean Sea, Somarakis et al. (2012) found a strong linear relationship between daily specific fecundity (DSF, number of eggs produced daily per gram of the stock) and the ratio of zooplankton biomass (estimated from plankton sampling) to adult biomass (estimated from concurrent acoustic surveys) (Fig. 9). In years with high zooplankton concentration (prey for adults), daily egg production is high and subsequently the abundance of anchovy ichthyoplankton is particularly elevated (Somarakis 2005, Somarakis \& Nikolioudakis 2007, Somarakis et al. 2011). Interestingly, there is a strong linear relationship between anchovy egg abundance and the mortality of larvae (density- dependent larval mortality, Fig. 9), which can be attributed to increased interspecific competition for food or increased predation pressure on the early life stages at high ichthyoplankton densities (Somarakis \& Nikolioudakis 2007, see also Agostini et al. 2007).

The Mediterranean anchovy is a characteristic example of a primarily income breeder with egg production strongly dependent on per capita food availability. As we will discuss in the next section, the strong density dependency of egg production and larval mortality is the result of a limited scope for expanding spawning habitats in the trophically heterogeneous Mediterranean Sea. 


\section{DENSITY-DEPENDENT HABITAT USE}

Small pelagic fish are known to exhibit large expansions and contractions of distributional range associated with levels of abundance (Fréon et al. 2005, Barange et al. 2009). In the Bay of Biscay, for example, there is a strong linear relationship between the extent of European anchovy spawning habitat and the spawning stock biomass (Somarakis et al. 2004). In the oligotrophic Mediterranean Sea, there is limited scope for expanding spawning habitats because suitable spawning areas (productive, continental shelf areas) are restricted in space and separated from each other by highly oligotrophic deep basins (see Fig. 10). Indeed, in comparing the relative variability in the extension of spawning habitats (SA, positive area for anchovy eggs) in relation to variability in $\mathrm{SSB}$, i.e. the $\mathrm{CV}(\mathrm{SA}): \mathrm{CV}(\mathrm{SSB})$ ratio, from annual egg production surveys, Somarakis et al. (2012) showed that the ratio was higher in the Bay of Biscay or off Chile compared to the Aegean Sea (eastern Mediterranean). The relative variability in daily specific fecundity (DSF), i.e. the CV(DSF): $\mathrm{CV}(\mathrm{SSB})$ ratio, was markedly higher in the Aegean Sea than in the other more productive areas. In other words, increased population density led to the decrease in fecundity in the Mediterranean Sea, but to the expansion of spawning habitats in the Bay of

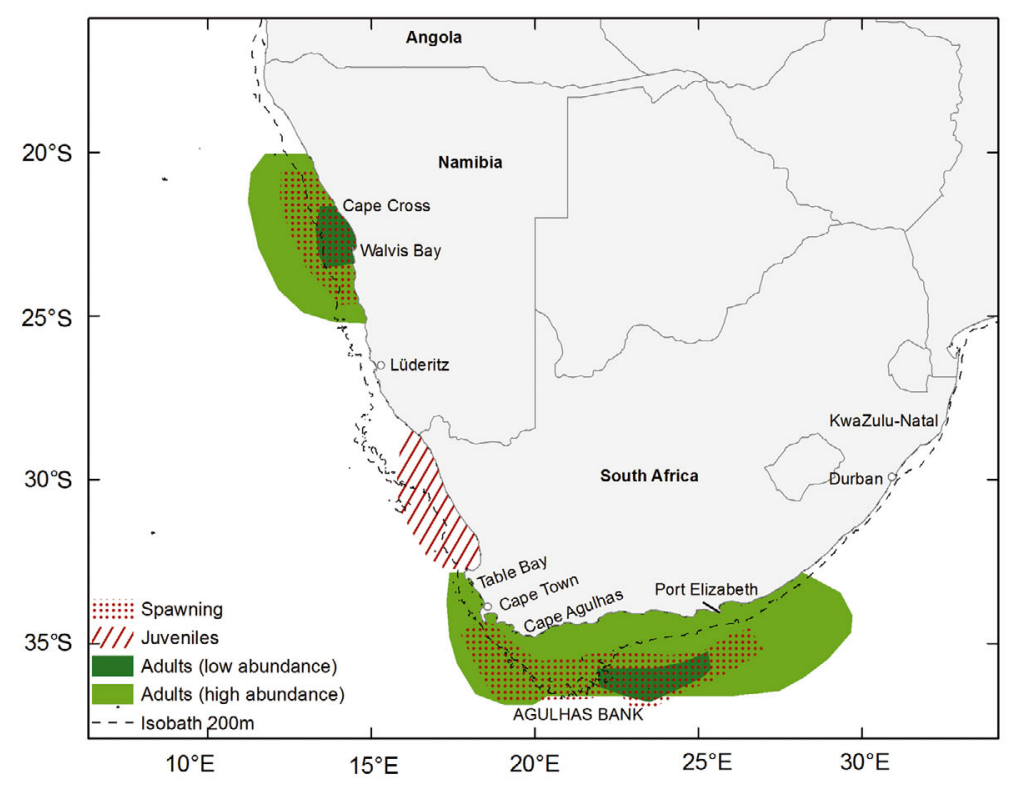

Fig. 10. Spawning and nursery grounds of European anchovy Engraulis encrasicolus in South African waters (top) and the Mediterranean Sea (bottom). Redrawn from Giannoulaki et al. (2014) and based on Schwartzlose et al. (1999), van der Lingen \& Huggett (2003), Checkley et al. (2009), Giannoulaki et al. (2013)

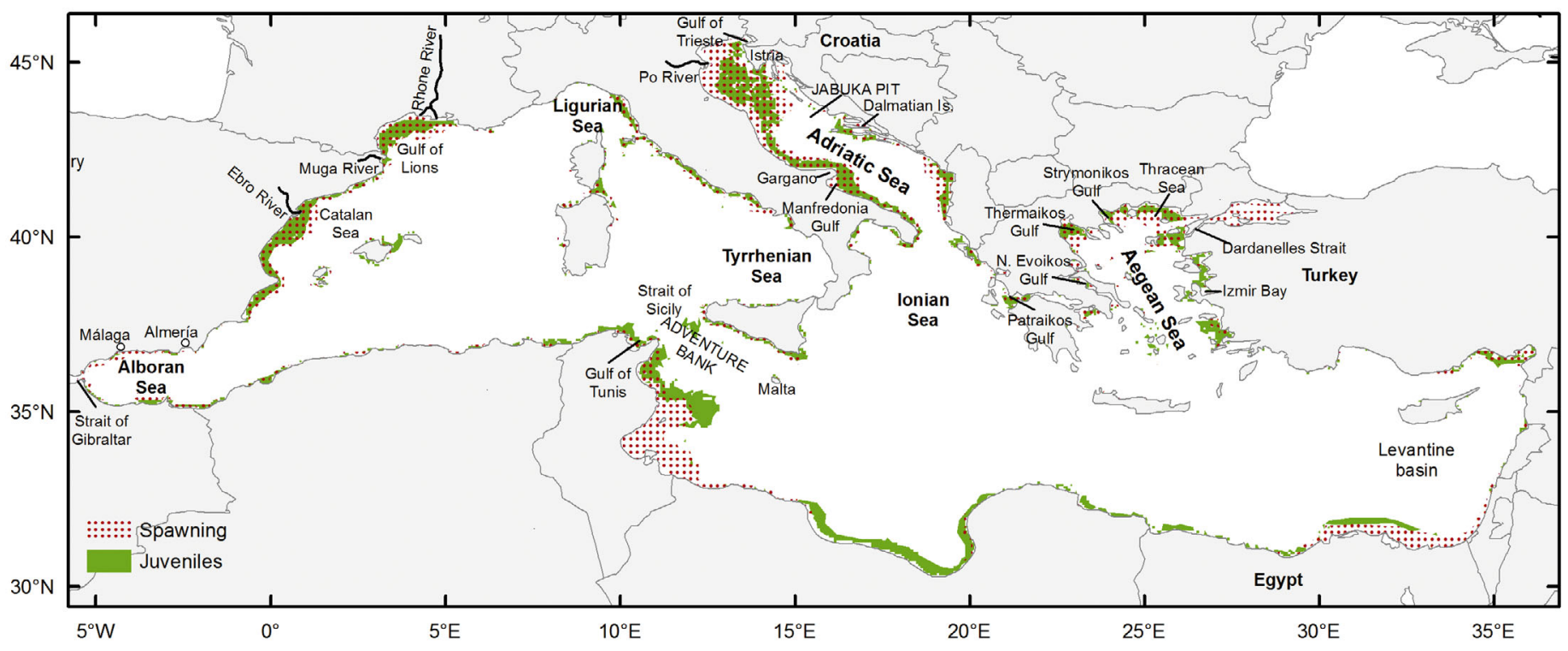


Biscay and the upwelling area. It should be added here that the areas of distribution of the major Mediterranean anchovy stocks have specific hydrographic and topographic features that promote the retention of eggs and larvae in the productive spawning areas like the shelf-break front in the western Mediterranean (Palomera et al. 2007), the high land enclosure of the Adriatic Sea and several retentive features (enclosed gulfs, fronts and anticyclones) in the North Aegean Sea (Somarakis \& Nikolioudakis 2007). High egg and larval retention (see also next section) is important for recruitment in the Mediterranean Sea because dispersal to offshore, extremely oligotrophic areas would be detrimental for larval survival.

Planque et al. (2007) separated the spawning habitat into potential, realized and successful to distinguish between habitat components, (1) where the environmental conditions are suitable for spawning, (2) where spawning actually occurs and (3) from where successful recruitment has resulted, respectively. The successful spawning habitats are bounded by their respective potential spawning habitats and are typically much smaller than them. Hence, the density-dependent expansion of spawning areas typically observed in open-ocean stocks (e.g. Bay of Biscay, upwelling areas) may not lead to increased recruitment. For example, in the NW Pacific, when the stock of Japanese sardine Sardinops melanostictus is at low biomass levels, spawning grounds are confined within inshore areas. In peak years of stock abundance during the 1980s, spawning grounds extended across the Kuroshio Current, leading to increased larval transport to the Kuroshio Extension and subsequently to recruitment failures (Watanabe 2002).

\section{SPATIAL SPAWNING PATTERNS IN RELA- TION TO EGG AND LARVAL ADVECTION}

Spatial spawning patterns (and the degree to which these vary in relation to population density) as well as the subsequent advection (retention or transport) of eggs and larvae are major determinants of the levels of uncertainty (interannual variability) in recruitment.

In general, fish stocks are believed to have evolved so that their early life stages develop and grow in areas with specific topographic and/or physical features that ensure sufficient local retention or the successful transport to a suitable nursery ground. Year class failures occur when there are significant deviations from average circulation patterns (Houde 2009).
Stocks with highly overlapping spawning and juvenile habitats are dependent on retention features (e.g. gyres, shelf break fronts, high land enclosure) whereas stocks with spatially segregated spawning and nursery grounds are usually dependent on specific circulation pathways.

Different stocks of the same SPF species may exhibit varying degrees of overlap between spawning and nursery habitats. For example, the stock of the European anchovy, Engraulis encrasicolus, in South Africa has discrete spawning and nursery grounds (Fig. 10) and a jet current provides the pathway for the transport of larvae to the nursery area which is nearly $500 \mathrm{~km}$ away from the spawning sites. Anomalies in transport success between the spawning and nursery area is one of the main agents causing the large variability in recruitment of the South African anchovy (Fréon et al. 2005 and references therein).

In the Mediterranean Sea, the same species has several distinct stocks characterized by highly overlapping spawning and nursery grounds (Fig. 10). As mentioned in the previous section, larval retention is very important in this region due to the patchy nature of suitable (productive) habitats and the hostile (highly oligotrophic) character of the adjacent offshore waters (Somarakis et al. 2004).

This is not the case for the European anchovy stock in the Bay of Biscay. In this area, the main spawning grounds of anchovy are located in coastal waters and larvae are advected offshore. Irigoien et al. (2007) suggested that this offshore advection of anchovy larvae in the Bay of Biscay represents a 'loophole' strategy (see 'Recruitment hypotheses') to minimize predation risk, which is particularly elevated over the continental shelf.

In longer-lived SPF that can eventually form large oceanic populations, the spatial (and in the case of certain herrings, the temporal) spawning patterns are primarily determined by population contingent structure (Petitgas et al. 2010 and references therein). Contingents are population components with different migration and larval dispersion patterns, i.e. processes that link the habitats used by the different life stages. The life cycle of each contingent is usually contained within a persistent oceanographic structure that ensures larval retention or transport and/or control migration of juveniles and/or adults. When a population is characterized by more than a single life cycle pattern, such contingents could be linked by straying of individuals through dispersal in the larval, juvenile and/or adult phases (Harden-Jones 1968, Sinclair 1988). For example, different herring 
contingents may use different spawning grounds or there may exist an inshore resident and an offshore migratory contingent as in the case of the Californian sardine. Behavioral processes, either based on individual physiology or based on social interaction (learning and memorizing) can determine the persistence of contingent structure and habitat-use patterns (reviewed in Petitgas et al. 2010). Fishery and/or environmentally induced reductions in the abundance of populations with complex life cycle patterns have often been associated with damage of contingent structure, social disruption and subsequent reduction of spatial distributions and spawning habitats.

\section{EFFECTS OF FISHING ON STOCK REPRODUCTIVE POTENTIAL AND SPAWNING PHENOLOGY}

Besides SSB depletion and possible damage to contingent structure or space-use pattern, human exploitation can also reduce the reproductive potential of stocks. Reproductive potential is the first step in the recruitment process (Solemdal 1997) and refers to the capacity of a fish stock to produce gametes and viable embryos. Annual population fecundity depends on the age or size and sex composition of the spawning stock whereas maternal effects (female size and condition) on egg size and biochemical composition can affect the survival potential of eggs and larvae. The maternal effects on egg quantity and quality have been extensively reviewed in Marshall (2009).

The stock reproductive potential of SPF stocks can be significantly affected by fishing when the fishery removals are selective and alter (truncate) the age or size structure of the stock. There are many small pelagic fisheries which are strongly size-selective. For example, in the North Aegean Sea purse seine fishery, fishermen clearly target schools with large individuals that fetch higher market prices (Somarakis et al. 2006b).

In general, larger or older fish produce many more eggs than smaller fish. In herring stocks, the relative annual fecundity is typically increasing significantly with female length (e.g. Óskarsson et al. 2002, Óskarsson \& Taggart 2006). Spawning time may also change with size with large fish spawning earlier than recruit spawners (e.g. Winters \& Wheeler 1996, Slotte et al. 2000).

In multiple spawning clupeoid stocks, especially sardine stocks, many reproductive parameters de- pend on fish size or age. Hence, selective fishing would greatly affect their stock reproductive potential (Ganias et al. 2014): recruit spawners often become sexually mature later in the year, or the duration of the spawning period is shorter in smaller fish (e.g. Parrish et al. 1986, Silva et al. 2006, Ganias et al. 2007, Cubillos \& Claramunt 2009). The spawning frequency (e.g. Ganias et al. 2003, Claramunt et al. 2007) and occasionally the relative batch fecundity $\left(\right.$ eggs g ${ }^{-1}$ ) (e.g. Somarakis et al. 2002, Claramunt et al. 1994) may increase with size. Finally, the few existing estimates of annual fecundity in anchovies and sardines (Parrish et al. 1986, Claramunt et al. 1994, Nunes et al. 2011) indicate a strong size or age dependency. For example, a 4 yr old female northern anchovy, Engraulis mordax, produces 10 times more eggs $\mathrm{g}^{-1}$ than a recruit (1 yr old) spawner (Parrish et al. 1986).

Finally, selectively removing the larger fish can affect the timing of peak spawning (Wright \& Trippel 2009). In the common sardine, Strangomera bentincki, several years of fishing off Chile resulted in a truncated length distribution, which, in combination with the significant effect of fish length on reproductive timing (Cubillos \& Claramunt 2009), led to a 2 mo shift in peak population spawning time (Cubillos et al. 2014). The consequences for recruitment and population sensitivity to climate change might be very important in this case.

\section{RECRUITMENT HYPOTHESES}

Most recruitment hypotheses (Table 1) have focused on survival during the early life stages. Starting from Hjort's 'critical period' and 'aberrant drift', they fall under one or two broad categories: (1) trophodynamic hypotheses that focus on food availability to the early life stages, and (2) hydrodynamic hypotheses that focus on transport or retention of early stages to and within appropriate nursery habitats. Moving further, Andrew Bakun formulated more synthetic theories such as the 'ocean triad' (Bakun 1996) that recognizes nutrient enrichment, nutrient concentration and offspring retention as the three critical features of successful larval habitats. Ocean triads enhance recruitment opportunities, but negative biotic interactions (i.e. competition and predation) can alternatively limit propagule survival and subsequently recruitment success. Thus, 'loophole strategies' (Bakun \& Broad 2003) may be used to minimize competition or predation intensity (e.g. Bertrand et al. 2004, Irigoien et al. 2007). 
Table 1. Prominent recruitment hypotheses formulated for marine fish

\begin{tabular}{|c|c|c|}
\hline Hypothesis & Reference & Driver of recruitment (larval survival) \\
\hline Critical period & Hjort (1914) & Food availability at the first-feeding stage \\
\hline Aberrant drift & Hjort (1914) & Unfavorable transport of eggs and larvae by ocean currents \\
\hline Match/mismatch & Cushing (1990) & Food availability \\
\hline Stable ocean & Lasker (1978) & $\begin{array}{l}\text { Calm, low-wind periods that promote aggregation of plank- } \\
\text { tonic organisms at discontinuities }\end{array}$ \\
\hline Optimal environmental window & Cury \& Roy (1989) & $\begin{array}{l}\text { Wind speeds that minimize offshore transport and maximize } \\
\text { larval-prey contact }\end{array}$ \\
\hline Member-vagrant & Iles \& Sinclair (1982) & Larval retention \\
\hline Growth-mortality & Anderson (1988) & Larval growth, a function of food availability and temperature \\
\hline
\end{tabular}

All recruitment hypotheses (trophodynamic or hydrodynamic) have merit and they are not mutually exclusive (Houde 2009). Many of them (Table 1), like critical period, aberrant drift, stable ocean, optimal environmental window and member-vagrant, have emerged from studies on clupeoid fish. Insight accumulated over the long history of recruitment research highlights that the key to understanding the variability in early stage survival lies not in identifying a single factor but a combination of interacting biological and physical factors.

Field investigations on the trophodynamic processes and the survival of the early life stages are not so straightforward. Despite advances in instruments and techniques, obtaining unbiased and precise estimates of the abundance of early stages, their prey and their predators, at the spatial and temporal scales over which they interact, has remained a great challenge (Heath 1992, Pepin 2004). Measuring variations in growth rates of field collected larvae and juveniles has proved more successful, and otolith microstructure analysis is an invaluable tool for this objective (Sponaugle 2010).

The rates of growth and mortality during the early life stages are tightly coupled in the framework of the 'growth-survival' paradigm ('growth-mortality' hypothesis, Anderson 1988). According to it, larger and/or faster growing larvae are more likely to survive. Three functional mechanisms linking growth rates and survival have been proposed (recently reviewed in Takasuka et al. 2017). According to the 'stage duration' mechanism (Houde 1987), good feeding conditions (and favorable temperatures) lead to faster growth, shorter duration of the larval stages and consequently lower cumulative mortality. The 'bigger is better' (Miller et al. 1988) and the 'faster is better' mechanisms (Anderson 1988) imply that mortality rates are inversely related to size (e.g. Vigliola \& Meekan 2002, Nielsen \& Munk 2004, Tanaka et al. 2006), and that smaller and/or slower- growing larvae are more susceptible to predation than larger or faster growing larvae (e.g. Takasuka et al. 2004). For example, Schismenou et al. (2014) analyzed the otolith microstructure of European anchovy juveniles in the eastern Mediterranean and found that individuals hatched towards the end of the protracted spawning period were larger at age and had wider otolith increments compared to fish spawned at the start and middle of the spawning season (Fig. 11). These findings implied a strong 'bigger' and 'faster' selection for the cohorts spawned late in the season, when temperature and food availability (e.g. microzooplankton, Fig. 11) were lower. Other more elaborate studies tested directly the 'bigger' or 'faster' selection either by comparing the original populations with the survivors (e.g. Robert et al. 2007), or the original populations and larvae from predator stomachs (e.g. Takasuka et al. 2003, 2004, 2007a).

The 'growth-survival' paradigm has been given much attention in studies of recruitment dynamics, but the increasing number of papers testing the 'bigger is better' and 'faster is better' hypotheses have been providing contradictory evidence for such sizeor growth-selectivity (e.g. Litvak \& Leggett 1992, Pepin et al. 1992, Takasuka et al. 2017). In many cases, the size- or growth-selection occurs in brief periods of larval development or in particular stages or years (e.g. Searcy \& Sponaugle 2001, Raventos \& Macpherson 2005, Murphy et al. 2014) whereas in other cases it depends on the size and taxon of predators (e.g. Takasuka et al. 2004).

Physical features and processes operating across many spatial scales (e.g. basin circulation, currents, hydrographic discontinuities, stratification, microturbulence) control the advection of eggs and larvae and mediate the prey-predator interactions (Werner et al. 1997). As ontogeny proceeds, both behavior and larval capabilities (e.g. vertical migration, swimming mode) are changing. Recognizing ontogenetic 


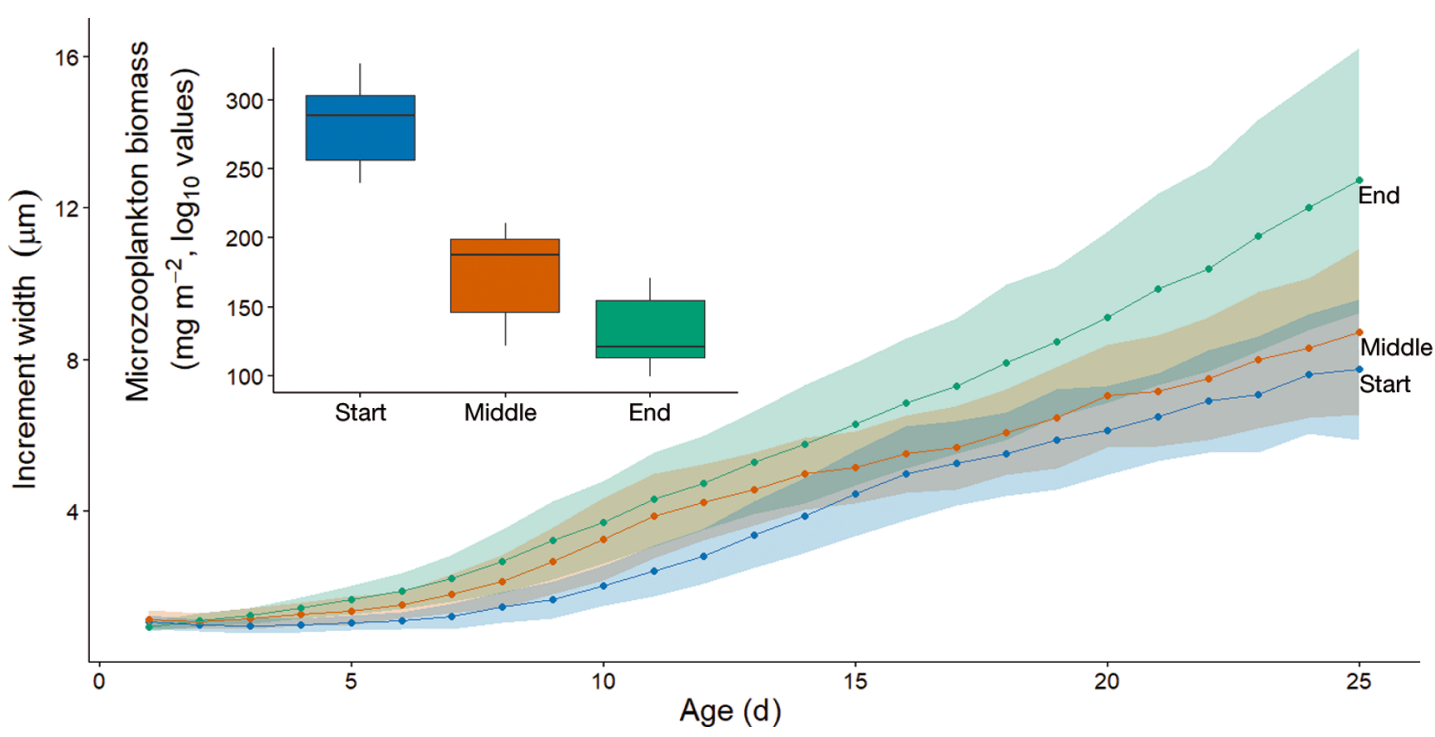

Fig. 11. Otolith widths-at-age for anchovy Engraulis encrasicolus juveniles hatched in the start (spring), middle (summer) and end (autumn) of the protracted spawning period. Box-plots of microzooplankton biomass derived from the simulation of a coupled hydrodynamic-biogeochemical model during the respective periods of increment formation are also shown. More details are provided in Schismenou et al. (2014). Boxes indicate median and interquartile ranges. Whiskers delineate full ranges

changes in larval performance is important because such changes can alter the relative importance of physical factors and modify the predator-prey interactions.

\section{ONTOGENETIC CHANGES}

Understanding ontogenetic transitions, especially those that are critical for the life of fish, is of prime importance in our attempt to determine factors that affect survival probabilities and control recruitment levels (Nikolioudakis et al. 2010). Most marine fishes have indirect development and complex life cycles with distinct ontogenetic intervals: embryo, larva, juvenile and adult. These major intervals have been generally recognized by both fishery scientists and fish biologists (both 'gradualists' [Fuiman 2002] and 'saltatorists' [Balon 1999]; see Kováč \& Copp 1999) as being characterized by different fish capabilities, requirements and ecological interactions (Nikolioudakis et al. 2010 and references therein). The transition from endogenous to exogenous feeding (Hjort's 'critical period') is the only widely acknowledged critical ontogenetic threshold prior to metamorphosis, with most ecological studies considering that larval performance during the feeding larval stage is a function of size (Somarakis \& Nikolioudakis 2010).

However, scientists working with anchovy and sardine in the California Current during the 1970s and early 1980s soon recognized that capabilities and the mortality rate of exogenously feeding larvae change significantly at some point during the larval phase, separating early and late larval stages (Smith 1985). Recently, Somarakis \& Nikolioudakis (2010) revealed that this change is related with the notochord flexion (Kendall et al. 1984) and the concomitant development of the caudal fin. The study of Somarakis \& Nikolioudakis (2010) on European anchovy showed that the flexion stage is associated with a change in functional morphology, a decrease in catchability with plankton nets (Somarakis et al. 1998), a sudden increase in spatial patchiness and the onset of swimbladder inflation and diel vertical migrations (Olivar et al. 2001, Sabatés et al. 2008). As suggested by John Hunter, the start of migrations to the surface to fill the swim-bladder increases the social contacts that are necessary for the development of schooling behavior, which is well established in northern anchovy, Engraulis mordax, in the early post-flexion stages (Hunter \& Sanchez 1976, Hunter \& Coyne 1982).

Apart from schooling, the flexion stage has been shown, in various SPF species, to be associated with a change in swimming mode (from anguilliform to subcarangiform), the improvement of swimming performance, the inflation of the auditory bullae, the proliferation of rod photoreceptors, the increase in the number of preys consumed and/or a change of prey type and size and the full establishment of foraging abilities (Table 2). 
Table 2. Evidence from published papers for changes associated with the notochord flexion and concomitant development of the caudal fin in SPF (based on Somarakis \& Nikolioudakis 2010)

\begin{tabular}{|c|c|c|}
\hline & Species & References \\
\hline Change in allometric growth & Engraulis encrasicolus & Somarakis \& Nikolioudakis (2010) \\
\hline $\begin{array}{l}\text { Change in swimming mode } \\
\text { (from anguilliform to subcarangiform) }\end{array}$ & Clupea harengus & Batty (1984) \\
\hline $\begin{array}{l}\text { Change from a viscous to an } \\
\text { inertial environment }\end{array}$ & $\begin{array}{l}\text { Clupea harengus, } \\
\text { Engraulis mordax }\end{array}$ & Batty (1984), Webb \& Weihs (1986) \\
\hline $\begin{array}{l}\text { Onset of inflation of the auditory bullae } \\
\text { and (or) proliferation of } \\
\text { rod photoreceptors }\end{array}$ & $\begin{array}{l}\text { Engraulis mordax, } \\
\text { Anchoa mitchilli, } \\
\text { Brevoortia tyrannus }\end{array}$ & O'Connell (1981), Higgs \& Fuiman (1996) \\
\hline Onset of gill raker formation & Engraulis anchoita & Vasconcellos et al. (1998) \\
\hline $\begin{array}{l}\text { Change in catchability with } \\
\text { plankton samplers }\end{array}$ & $\begin{array}{l}\text { Engraulis encrasicolus, } \\
\text { Engraulis anchoita }\end{array}$ & Somarakis et al. (1998), Vasconcellos et al. (1998) \\
\hline Onset of diel vertical migrations & $\begin{array}{l}\text { Engraulis mordax, } \\
\text { Engraulis encrasicolus }\end{array}$ & $\begin{array}{l}\text { Hunter \& Sanchez (1976), Olivar et al. (2001), } \\
\text { Sabatés et al. (2008) }\end{array}$ \\
\hline Onset of swim-bladder inflation & $\begin{array}{l}\text { Engraulis japonicus, } \\
\text { Engraulis mordax, } \\
\text { Brevoortia tyrannus, } \\
\text { Engraulis encrasicolus }\end{array}$ & $\begin{array}{l}\text { Uotani (1973), Hunter \& Sanchez (1976), } \\
\text { Forward et al. (1993), } \\
\text { Somarakis \& Nikolioudakis (2010) }\end{array}$ \\
\hline Change in spatial patchiness & $\begin{array}{l}\text { Engraulis mordax, } \\
\text { Engraulis anchoita, } \\
\text { Engraulis encrasicolus }\end{array}$ & $\begin{array}{l}\text { Hewitt (1981), Vasconcellos et al. (1998), } \\
\text { Somarakis \& Nikolioudakis (2010) }\end{array}$ \\
\hline Onset of schooling & Engraulis mordax & Hunter \& Coyne (1982) \\
\hline $\begin{array}{l}\text { Change in otolith growth } \\
\text { (increment widths) }\end{array}$ & $\begin{array}{l}\text { Herklotsichthys castelnaui, } \\
\text { Engraulis encrasicolus }\end{array}$ & $\begin{array}{l}\text { Thorrold \& Williams (1989), } \\
\text { Somarakis \& Nikolioudakis (2007) }\end{array}$ \\
\hline $\begin{array}{l}\text { Increase in number of prey consumed } \\
\text { and/or change of prey type and size }\end{array}$ & $\begin{array}{l}\text { Engraulis encrasicolus, } \\
\text { Engraulis anchoita }\end{array}$ & $\begin{array}{l}\text { Coombs et al. (1997), } \\
\text { Vasconcellos et al. (1998) }\end{array}$ \\
\hline Full establishment of foraging abilities & Sardina pilchardus & Garrido et al. (2016) \\
\hline
\end{tabular}

Table 3. Calculations of the M:G ratio (M: daily mortality rate, G: weight specific daily growth rate) for the early larval and late larval stage of European anchovy in the North Aegean Sea (eastern Mediterranean) based on available literature data

\begin{tabular}{|c|c|c|c|c|c|c|c|}
\hline Stage & $\begin{array}{l}\text { Total length } \\
(\mathrm{mm})^{\mathrm{a}}\end{array}$ & $\begin{array}{l}\text { Growth rate } \\
\left(\mathrm{mm} \mathrm{d}^{-1}\right)\end{array}$ & $\begin{array}{l}\text { Stage duration } \\
\text { (d) }\end{array}$ & $\begin{array}{l}\text { Initial dry } \\
\text { weight }(\mathrm{g})^{\mathrm{d}}\end{array}$ & G & M & M:G \\
\hline Early larva & $3.5-11$ & $0.49^{b}$ & 15.31 & $1.06 \times 10^{-5}$ & 0.251 & $0.258^{\mathrm{b}}$ & 1.030 \\
\hline Late larva & $11-40$ & $0.80^{\mathrm{c}}$ & 36.25 & 0.000492 & 0.119 & $0.055^{\mathrm{e}}$ & 0.461 \\
\hline Juvenile & $>40$ & & & 0.0371 & & & \\
\hline
\end{tabular}

The development of the caudal fin is an important milestone in fish ontogeny (Somarakis \& Nikolioudakis 2010) with late (postflexion) larvae performing better and having superior growth and survival rates than early (preflexion) larvae (e.g. Table 3). Indeed, based on available information (Table 3), we calculated that the average $\mathrm{M}$ :G ratio, i.e. the ratio of daily mortality to weight specific growth rate, is almost two times lower (and much lower than 1) in the late than the early larval stage for European anchovy in the eastern Mediterranean.
The M:G ratio is considered as an index of fitness, and the age or size at which the ratio shifts from $>1$ to $<1$ ('transition stage') can be an indicator of recruitment potential, i.e. 'transition' at earlier (younger, smaller) stages often is inversely correlated with recruitment level (Houde 1997, 2009). As we will discuss in the next section the transition from early to late larval stage in the Mediterranean anchovy is fast, and associated changes in performance are abrupt and easy to recognize because of the high temperatures experienced by the larvae in this basin. 


\section{TEMPERATURE EFFECTS}

Among the physical and chemical properties of seawater, temperature is commonly important in all ecosystems (Pörtner \& Farrell 2008, Pörtner \& Peck 2010). First, temperature controls prey availability through its effect on the levels and timing of planktonic production (e.g. match/mismatch hypothesis, Cushing 1990). Secondly, temperature is a major driver of energetic processes. Food consumption, levels of activity (swimming speed, encounters with predators) and metabolism (e.g. respiration rate) are strongly temperature-dependent (e.g. Kitchell et al. 1977). For example, food intake increases with increasing temperature, reaches a peak and then falls more or less dramatically at supra-optimal temperature (Jobling 1998). Whereas in northern latitudes fish are unlikely to experience supra-optimal temperatures, this can be common in tropical and subtropical ecosystems. In the eastern Mediterranean for instance, field studies (Nikolioudakis et al. 2011, 2014a) have shown that, in winter, when the water column is mixed, anchovy and sardine juveniles and adults feed during both day and night. However, in summer, food consumption stops in the night hours when the fish are dispersed in the surface mixed layer. Surface waters reached $27^{\circ} \mathrm{C}$ during the study (Nikolioudakis et al. 2014a), which was well above the optimum temperature for consumption.

Besides consumption, temperature affects all component rates of the energy budget and, ultimately, growth rate. For example, reported values of weightspecific growth rate (G) for larval Atlantic herring vary approximately 10 -fold over 6 to $17^{\circ} \mathrm{C}$ (Houde 1989). In their recent review, Peck et al. (2013) revealed that thermal niches (optimal and sub-optimal ranges in temperatures) were species- and stage-specific for anchovies and sardines in nonupwelling systems and argued that gaining a cause and effect understanding of climate-driven changes in SPF will require detailed information on the ecophysiology of the different species.

In the eastern Mediterranean, Schismenou et al. $(2014,2016)$ studied the effect of temperature and other ecosystem parameters on the daily growth rate of European anchovy and European sardine in the field using otolith microstructure analysis and simulations of a hydrodynamic-biogeochemical model. Using a statistical modelling approach that accounted for the uncoupling of otolith and somatic growth (the 'inherent otolith growth'), they found that the co-occurring species had the same temperature optima for early growth, at about $24.5^{\circ} \mathrm{C}$. In other ecosystems like the NW Pacific, the larvae of anchovy and sardine have different temperature optima (Takasuka et al. 2007b) which might be an explanation for the anchovy and sardine population alternations (the 'Optimal growth temperature hypothesis').

Across taxa and ecosystem analyses (e.g. Houde 1989, Pepin 1991) have demonstrated that both growth and mortality rate in larval fishes increase with temperature. Furthermore, the point of no return (PNR), the time required for a first feeding larvae to feed exogenously before irreversible starvation, decreases exponentially with temperature (Pepin 1991). The PNR can be reached in a single day for small clupeoid larvae in tropical ecosystems but this can take as long as 10 to $20 \mathrm{~d}$ for herrings (Houde 2009).

Temperature also affects the somatic and behavioral ontogeny. Ontogeny is slow and gradual at low temperatures and fast or saltatory in warmer waters (Somarakis \& Nikolioudakis 2010, Nikolioudakis et al. 2014b). The size at ontogenetic transitions, e.g. the length at metamorphosis, decreases with temperature (Fuiman et al. 1998), and morphological transitions are more abrupt and synchronized among traits at higher temperatures (Nikolioudakis et al. 2014b). This is, for example, evident in the otolith growth pattern, which changes from increasing to decreasing increment widths during metamorphosis: increment width trajectories are more 'leptokurtic' at high temperatures and 'platykurtic' at low temperatures (Schismenou et al. 2016).

In a recent laboratory experiment, Garrido et al. (2016) tested the effect of temperature on larval European sardine ontogeny and foraging behavior. The completion of the notochord flexion occurred at $13 \mathrm{~mm}$ when sardine was reared at $15^{\circ} \mathrm{C}$ and at about $11 \mathrm{~mm}$ at $17^{\circ} \mathrm{C}$. Time spent swimming reached a plateau at the end of the flexion stage whereas changes in important foraging parameters, such as the number of fixations and attacks on prey, changed gradually during the low temperature treatment and abruptly at the higher temperature, being clearly associated with the completion of the notochord flexion.

Temperature also has an important effect on stage durations. Lower temperatures lead to longer larval durations, potentially longer dispersal distances and higher cumulative mortalities (O'Connor et al. 2007). Houde (2009) suggested that because variability in stage durations is highest in fishes from cold seas, like the Atlantic herring (Houde 1989), the temperature effect on stage durations is probably a more sig- 
nificant contributor to recruitment variability at high latitudes than at low latitudes.

Table 4 summarizes parameters that are affected by temperature and are considered important for the fecundity and early survival of clupeoids. The list in Table 4 is based on knowledge summarized in this paper and includes the rate of vitellogenesis and frequency of spawning (see 'Reproductive strategies and egg production') and parameters such as planktonic duration, maintenance cost, time to PNR, rate of growth and mortality, as well as ontogenetic and behavioral development. Temperature regimes are quite different for herrings in the north, sardines and anchovies spawning in cool and mixed waters (upwelling or winter conditions) and species reproducing in thermally stratified waters. Spawning of SPF in ecosystems characterized by low, intermediate and high temperatures, respectively, are expected to have dissimilar energetic requirements and different prospects for egg production and larval survival.

\section{DISCUSSION AND SYNTHESIS}

The question of the relationship of recruitment to spawning stock biomass has a long history. Myers \& Barrowman (1996) showed that low spawning biomass results in low recruitment. However, low spawning stock and low recruitment can be explained equally well by low recruitment generating low spawning stock (Szuwalski et al. 2015). It was beyond the scope of this paper to examine if variability in spawning stock or number of recruits drives the relationship. Additionally, despite the weak predictive power of stock-recruit relationships (Cury et al. 2014), it is unrealistic to assume no relationship (Hilborn et al. 2017) or the absence of densitydependent recruitment (Rose et al. 2001).
The analysis made for clupeoid stocks in this study showed that $60 \%$ of the examined stocks had significant $(\mathrm{p}<0.05)$ density-independent $(a)$ and densitydependent $(b)$ coefficients and did not exhibit any obvious trend in the residuals of the Ricker model indicative of changing stock productivity (Britten et al. 2016). The strength of the Ricker fit was significantly correlated with recruitment autocorrelation implying that, the stronger the dependence of recruitment on the environmental forcing, the better the fit of the spawner-recruit relationship. Maximum recruitment capacity of the stocks was negatively correlated with the coefficient of variation of $R$ (expressing mainly the interannual variability) and positively (and independently) related with recruitment autocorrelation (low frequency variability).

We argued that the relative importance of high and low frequency variability in recruitment that combine to generate the population fluctuations of SPF can be influenced by the adult breeding strategy and spawning patterns in combination with the thermal, oceanographic and trophic conditions of the ecosystem. The close spatial and temporal association of egg production with adult energy acquisition (feeding) and a spawning habitat that facilitates the subsequent retention and fast development and growth of larvae will most likely result in high recruitment autocorrelation. On the other hand, increased dispersal distances due to low incubation temperatures and/or a life cycle pattern that includes the transport of eggs and larvae from the spawning ground to a distant nursery are expected to increase uncertainty in recruitment and decrease the recruitment capacity of the stocks.

We will further elaborate on this by comparing the recruitment time series of two stocks with contrasting life history and habitats, a Canadian herring stock (Scotian shelf \& Bay of Fundy) and a Mediterranean anchovy stock (Adriatic anchovy) (Fig. 12). The Scot-

Table 4. Expected temperature effects on important reproductive and early life stage variables of SPF in different spawning habitats (see 'Temperature effects' for details)

\begin{tabular}{|lccc|}
\hline & $\begin{array}{c}\text { Boreal ecosystems } \\
\text { (herrings) }\end{array}$ & $\begin{array}{c}\text { Upwelling \& mixed } \\
\text { (winter) water columns }\end{array}$ & $\begin{array}{c}\text { Thermally stratified } \\
\text { (summer) waters }\end{array}$ \\
\hline Rate of vitellogenesis & Very slow & Fast & Faster \\
Frequency of spawning & Once & Low & High \\
Planktonic duration & Long & Short \\
Maintenance cost & Low & High & Very high \\
Time to PNR & Long & Short & Very short \\
Larval growth \& mortality & Low & High \\
Ontogenetic \& behavioral development & Slow, gradual & Fast & Very fast, saltatory \\
\hline
\end{tabular}



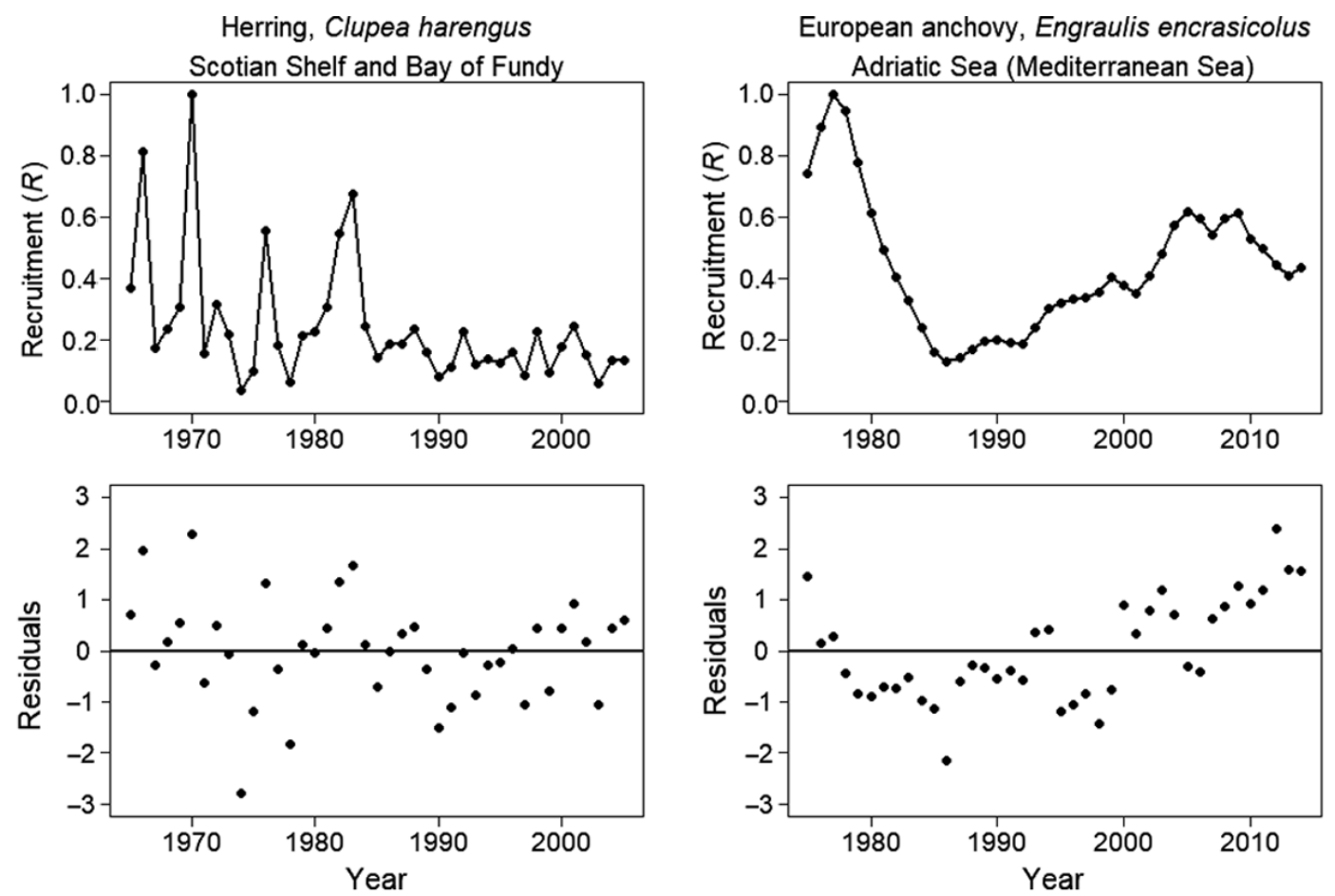

Fig. 12. Stocks with contrasting patterns of recruitment fluctuations. Upper panels: Yearly evolution of normalized recruitment. Lower panels: Normalized residuals of the Ricker model against time

ian shelf herring display high interannual variability and no significant autocorrelation in $R$. In contrast, recruitment of the Adriatic Sea anchovy is highly autocorrelated with the residuals of the fitted Ricker curve showing an initial decline followed by a reversing increasing trend, i.e. a continuously changing stock productivity.

The Scotian shelf herring has a life history strategy characterized by a long life span ( $>11$ yr) and delayed maturity $(\sim 4 \mathrm{yr})$, spreading reproductive effort over many years (high offspring survivorship during one year offsets the numerous bad years). Eggs are deposited during autumn in precisely localized spawning areas and the larvae hatch after 1 to $3 \mathrm{wk}$. They develop over a period of very low temperatures and low food abundance and they do not metamorphose until the following spring when they may be 5 to 8 mo old (Townsend 1992). Townsend (1992) reviewed existing studies from several areas in the NW and NE Atlantic and suggested that the particular locations of spawning beds in relation to the temporally varying location of oceanographic features, such as tidal fronts and geostrophic currents, can induce high interannual variability in the retention vs. transport of hatching herring cohorts. This, in combination with the prolonged and variable larval durations, can explain the high variability and/or low autocorrelation observed in most herring recruitment series. It is interesting to note that (with the exception of one small stock in the North Baltic Sea, ICES 31) all herring stocks inhabiting areas with increased land enclosure (Baltic Sea, North Sea, Strait of Georgia) displayed statistically significant ( $p<0.05$ ) autocorrelation in $R$ in contrast to herring stocks with spawning grounds more exposed to the ocean (see Table S4 in the Supplement). The latter had on average higher variability in recruitment and low maximum recruitment capacity (Table S4). Presumably, the increased land enclosure contributes to increased retention, allowing for decreased interannual variability and closer association of recruitment levels with the environmental forcing.

The life history strategy of the Adriatic Sea anchovy is characterized by early maturation $(<1 \mathrm{yr})$, frequent reproduction over an extended spawning season (from early spring to late autumn) and rapid larval growth (Morello \& Arneri 2009). Due to the high surface temperatures in summer (up to $28^{\circ} \mathrm{C}$ in the Adriatic), the time needed for an anchovy larva to reach the less vulnerable, schooling (postflexion) stage is 10 to $20 \mathrm{~d}$ (e.g. Table 3). The adults feed and spawn mainly in the river-enriched northwestern part of the basin (Morello \& Arneri 2009) and the presence of a salinity front and the Italian peninsula 
result in high larval retention. Density-dependent controls, related to per capita food availability and/or increased predation pressure at higher densities (like those described in this paper for fecundity and larval mortality of Mediterranean anchovy) could stabilize recruitment levels resulting in increased temporal autocorrelation in $R$. As pointed out by Rose et al. (2001), environmental fluctuations may not simply act as density-independent factors, but also potentially cause density-dependent responses.

In highly productive oceanic habitats like upwelling systems, suitable trophic habitats are extensive in space, temperatures are cool (but still much higher than the boreal herring habitats) but risks due to unfavorable transport (offshore Ekman transport) are particularly high (Cury \& Roy 1989, Bakun 1996). Ichthyoplankton retention is a crucial element for reproductive success in the Eastern Boundary Upwelling Systems (EBUSs) but the main spawning periods of clupeoid stocks in the EBUSs match either the season of maximal ichthyoplankton retention over the continental shelf (mainly sardines) or the maximal zooplankton concentration, i.e. adult prey availability (mainly anchovies) (Brochier et al. 2011). Our analysis showed that the stocks inhabiting such ecosystems displayed a wide range of values of coefficient of variation and autocorrelation in $R$, but only a few EBUS stocks were available for analysis to allow the identification of any useful pattern.

Interannual variation in recruitment reflects both the general magnitude of compensation in the population (ability to adjust to new densities) and fluctuations in recruitment owing to environmental variation (Rose et al. 2001). Most clupeoid stocks had significant density-dependent coefficients, but the magnitude of density dependence could not be connected to different ecosystems or species, except that the American herrings (NE Pacific and NW Atlantic) displayed higher coefficients of density dependence compared to other species groups like the NE Atlantic herrings. The American herrings have been fished at lower average rates and we showed that fishing mortality influences the stock-recruit relationship, being negatively correlated with the coefficient of density dependence. The stronger density dependence at elevated stock sizes in the American herrings could result from the benthic egg stage and the spatial constraints on suitable spawning substrates. High egg mortalities at high stock sizes can result from suffocation and increased predation or cannibalism on the large egg mats (Nash et al. 2009 and references therein).

In anchovy and sardine stocks, large-scale movements related to density is probably a mechanism leading to density-dependent recruitment. Presumably, such movements force the individuals to occupy inferior habitats when crowded (MacCall 1990). Whenever mortality and reproductive success depend upon a habitat that is variable in quality, the movement of individuals to suboptimal habitats when densities are high can result in compensatory density dependence (Rose et al. 2001).

In contrast to the extreme capital breeding of herrings, multiple spawning clupeoids are plastic; they can move along the capital-income breeding continuum in response to their energy reserves and the match/mismatch between the production of their planktonic food and the production of eggs (e.g. Gatti et al. 2017). Annual fecundity is difficult to measure in multiple spawning small pelagics, but existing evidence suggest that it may vary largely in relation to food intake, the adult nutritional condition and the size or age of fish. Investigations on SPF reproductive potential and how this is affected by the environment and fishing are still very scarce and more research is needed to elucidate its effect on recruitment success.

The understanding of variability in larval survival lies in identifying a combination of interacting biological and physical factors acting across many spatial scales. In order to fully appreciate how the larvae respond to the biotic and abiotic environment, it is important to recognize all important milestones in ontogeny associated with significant changes in capabilities and behavior. The onset of schooling is obviously a major milestone for SPF and, at least in anchovies, schooling behavior is established soon after the completion of notochord flexion in conjunction with other important changes in performance. Less is known regarding the late larval stages of herrings. However, as discussed in this paper, the functional and behavioral development is expected to be gradual and less synchronized in boreal ecosystems. In contrast to anchovies, schooling in Atlantic herring is being established at the end of metamorphosis and its characteristics continue to evolve throughout the early juvenile stage (Gallego \& Heath 1994).

The present paper focused on aspects of the adult and early life stages of SPF related to spawning, egg production and early life survival. Other aspects like the juvenile and/or adult migrations were only marginally considered although, for many large stocks, a migratory triangle (Harden Jones 1968) may be in place, and the spatial dynamics are of prime importance for life cycle closure, population dynamics and interactions with other ecosystem components (Huse 2016). The improved knowledge and modelling of the full life cycle including migration and inter- 
actions with other species in the ecosystem will certainly improve our understanding and ability to predict the drivers of population fluctuations.

Although coupled biophysical models of the early life stages (ELS) (reviewed in Lett et al. 2009) can help to identify and understand bottom-up factors influencing growth and survival of SPF (e.g. Baumann et al. 2006, Allain et al. 2007, Daewel et al. 2008, 2011, Dickey-Collas et al. 2009, Huret et al. 2010, Brochier et al. 2011, Xu et al. 2015), predicting responses of the early life stages is necessary but not sufficient to address all agents involved in determining the year class strength. First, recruitment for some species may not be determined until later in the life cycle than is simulated with ELS models (Lett et al. 2009). Secondly, the characteristics of the juvenile and adult stages and the influences of the environment and human exploitation on these stages cannot be adequately considered with ELS models.

Recently, 3-D full-life-cycle bioenergetics individual-based models (IBMs), coupled with hydrodynamic-biogeochemical models, which can also include fishing and predator modules have been developed for SPF in certain ecosystems, representing new, state of the art tools for simulating population variability in space and time (Politikos et al. 2015, Rose et al. 2015). The main advantages of such coupled, full-life-cycle models are that they allow for the direct linking of growth, mortality, movement and spawning processes to the detailed spatial and temporal scales of the hydrodynamic-biogeochemical models, and they can be used in multigenerational simulations to investigate the effects of climate and fishing (e.g. Fiechter et al. 2015, Stergiou et al. 2016). The adequate parameterization, calibration and validation of such complex models requires baseline programs of biological (including zooplankton) and fisheries monitoring as well as physiological- and behavioral-based laboratory experiments on both the early and adult life stages (Peck et al. 2013).

Acknowledgements. S.S. thanks the symposium convenors, Jürgen Alheit and Yoshioki Oozeki (ICES/PICES Symposium on Drivers of Dynamics of Small Pelagic Fish Resources, Victoria, BC, Canada, March 2017), and particularly the convenors of session 2: 'External drivers of change in early life history, growth and recruitment processes of small pelagic fish', David Checkley, Susana Garrido, Pierre Petitgas and Akinori Takasuka, for their invitation and support of his attendance and presentation of the keynote address on which this paper was based. The General Fisheries Commission for the Mediterranean (GFCM) sponsored the travel of S.S to Victoria, Canada. The guest editor and three anonymous reviewers provided insightful comments that greatly improved the manuscript.

\section{LITERATURE CITED}

Agostini V, Bakun A, Francis RC (2007) Larval stage controls on Pacific sardine recruitment variability: high zooplankton abundance linked to poor reproductive success. Mar Ecol Prog Ser 345:237-244

Allain G, Petitgas P, Lazure P, Grellier P (2007) Biophysical modelling of larval drift, growth and survival for the prediction of anchovy (Engraulis encrasicolus) recruitment in the Bay of Biscay (NE Atlantic). Fish Oceanogr 16: 489-505

Anderson JT (1988) A review of size dependent survival during pre-recruit stages of fishes in relation to recruitment. J Northwest Atl Fish Sci 8:55-66

Anderson CNK, Hsieh C, Sandin SA, Hewitt R and others (2008) Why fishing magnifies fluctuations in fish abundance. Nature 452:835-839

Bakun A (1996) Patterns in the ocean: ocean processes and marine population dynamics. California Sea Grant, San Diego, CA

Bakun A, Broad K (2003) Environmental 'loopholes' and fish population dynamics: comparative pattern recognition with focus on El Niño effects in the Pacific. Fish Oceanogr 12:458-473

Balon EK (1999) Alternative ways to become a juvenile or a definitive phenotype (and on some persisting linguistic offenses). Environ Biol Fishes 56:17-38

Barange M, Coetzee J, Takasuka A, Hill K and others (2009) Habitat expansion and contraction in anchovy and sardine populations. Prog Oceanogr 83:251-260

* Basilone G, Guisande C, Patti B, Mazzola S and others (2006) Effect of habitat conditions on reproduction of the European anchovy (Engraulis encrasicolus) in the Strait of Sicily. Fish Oceanogr 15:271-280

Batty RS (1984) Development of swimming movements and musculature of larval herring (Clupea harengus). J Exp Biol 110:217-229

* Baumann $\mathrm{H}$, Hinrichsen HH, Möllmann C, Köster FW, Malzahn AM, Temming A (2006) Recruitment variability in Baltic Sea sprat (Sprattus sprattus) is tightly coupled to temperature and transport patterns affecting the larval and early juvenile stages. Can J Fish Aquat Sci 63: 2191-2201

* Bertrand A, Segura M, Gutierrez M, Vasquez L (2004) From small-scale habitat loopholes to decadal cycles: a habitat-based hypothesis explaining fluctuation in pelagic fish populations off Peru. Fish Fish 5:296-316

* Bindman AG (1986) The 1985 spawning biomass of the northern anchovy. CalCOFI Rep 27:16-24

Blaxter JHS, Hunter JR (1982) The biology of the clupeoid fishes. Adv Mar Biol 20:1-223

Bowers AB, Holliday FGT (1961) Histological changes in the gonad associated with the reproductive cycle of the herring (Clupea harengus L.). Mar Res Dep Agric Fish Scot 5:1-16

Braun M, Claramunt G, Reyes H, Cataste V, Montenegro C, Baros V, Díaz E, Pizarro J, Pizarro P (2004) Evaluación del stock desovante de anchoveta en la I y II regiones, año 2003. Inf. Téc. FIP-IT/2003-07

Britten GL, Dowd M, Worm B (2016) Changing recruitment capacity in global fish stocks. Proc Natl Acad Sci USA 113:134-139

* Brochier T, Lett C, Fréon P (2011) Investigating the 'northern Humboldt paradox' from model comparisons of small pelagic fish reproductive strategies in eastern boundary upwelling ecosystems. Fish Fish 12:94-109

Casavola N, Ruggieri P, Rizzi E, Caputo S (1998) Daily egg 
production method for spawning biomass estimates of sardine in the south-western Adriatic Sea. Rapp Comm Int Mer Medit 35:396-397

Checkley DM, Ayon P, Baumgartner TR, Bernal M and others (2009) Habitats. In: Checkley DM, Alheit J, Oozeki Y, Roy C (eds) Climate change and small pelagic fish. Cambridge University Press, New York, NY, p 12-44

Claramunt G, Herrera G, Pizarro P (1994) Potential annual production of eggs according to sizes of Sardinops sagax in northern Chile. Rev Biol Mar Valparaiso 29:211-233

Claramunt G, Serra R, Castro LR, Cubillos L (2007) Is the spawning frequency dependent on female size? Empirical evidence in Sardinops sagax and Engraulis ringens off northern Chile. Fish Res 85:248-257

Clarke TA (1987) Fecundity and spawning frequency of the Hawaiian anchovy or nehu, Encrasicholina purpurea. Fish Bull 85:127-138

Coombs SH, Giovanardi O, Conway DVP, Manzueto L, Halliday NC, Barrett CD (1997) The distribution of eggs and larvae of anchovy (Engraulis encrasicolus) in relation to hydrography and food availability in the outflow of river Po. Acta Adriat 38:33-47

Cotero-Altamirano CE, Green-Ruiz YA (1997) Spawning biomass of the northern anchovy (Engraulis mordax) in the Gulf of California during 1991. CalCOFI Rep 38: 171-179

Cubillos LA, Claramunt G (2009) Length-structured analysis of the reproductive season of anchovy and common sardine off central southern Chile. Mar Biol 156:1673-1680

Cubillos LA, Ruiz P, Claramunt G, Gacitúa S and others (2007) Spawning, daily egg production, and spawning stock biomass estimation for common sardine (Strangomera bentincki) and anchovy (Engraulis ringens) off central southern Chile in 2002. Fish Res 86:228-240

Cubillos LA, Claramunt G, Castro LR (2014) Simulation of fishery-induced changes on the reproductive cycle of common sardine, Strangomera bentincki, off central southern Chile. Fish Res 160:103-111

Cunha EM, Figueiredo I, Farinha A, Santos M (1992) Estimation of sardine spawning biomass off Portugal by the daily egg production method. Bol Inst Esp Oceanogr 8: 139-153

Cury P, Roy C (1989) Optimal environmental window and pelagic fish recruitment success in upwelling areas. Can J Fish Aquat Sci 46:670-680

Cury P, Fromentin JM, Figuet S, Bonhommeau S (2014) Resolving Hjort's dilemma: How is recruitment related to spawning stock biomass in marine fish? Oceanography (Wash DC) 27:42-47

Cushing DH (1990) Plankton production and year class strength in fish populations: an update of the match/mismatch hypothesis. Adv Mar Biol 26:249-293

*Daewel U, Peck MA, Kühn W, St John MA, Alekseeva I, Schrum C (2008) Coupling ecosystem and individualbased models to simulate the influence of environmental variability on potential growth and survival of larval sprat (Sprattus sprattus L.) in the North Sea. Fish Oceanogr 17:333-351

Daewel U, Peck MA, Schrum C (2011) Life history strategy and impacts of environmental variability on early life stages of two marine fishes in the North Sea: an individual-based modelling approach. Can J Fish Aquat Sci 68: 426-443

Dickey-Collas M, Bolle LJ, van Beek JKL, Erftemeijer PCA (2009) Variability in transport of fish eggs and larvae. II. Effects of hydrodynamics on the transport of Downs herring larvae. Mar Ecol Prog Ser 390:183-194
Dickey-Collas M, Hintzen NT, Nash RDM, Schön PJ, Payne MR (2015) Quirky patterns in time-series of estimates of recruitment could be artefacts. ICES J Mar Sci 72: 111-116

Economou AN (1991) Is dispersal of fish eggs, embryos and larvae an insurance against density dependence? Environ Biol Fishes 31:313-321

Fiechter J, Rose KA, Curchitser EN, Hedstrom KS (2015) The role of environmental controls in determining sardine and anchovy population cycles in the California Current: Analysis of an end-to-end model. Prog Oceanogr 138: 381-398

FFletcher WJ, Lo NCH, Hayes EA, Tregonning RJ, Blight SJ (1996) Use of the daily egg production method to estimate the stock size of Western Australian sardines (Sardinops sagax). Mar Freshw Res 47:819-825

Forward RB, McKelvey LM, Hettler WF, Hoss DE (1993) Swim-bladder inflation of the Atlantic menhaden Brevoortia tyrannus. Fish Bull 91:254-259

Fréon P, Cury P, Shannon L, Roy C (2005) Sustainable exploitation of small pelagic fish stocks challenged by environmental and ecosystem changes: A review. Bull Mar Sci 76:385-462

Fuiman LA (2002) Special considerations of fish eggs and larvae. In: Fuiman LA, Werner RG (eds) Fishery science: the unique contributions of early life stages. Blackwell Publishing, Oxford, p 1-32

Fuiman LA, Poling KR, Higgs DM (1998) Quantifying developmental progress for comparative studies of larval fishes. Copeia 1998:602-611

*Gallego A, Heath MR (1994) The development of schooling behaviour in Atlantic herring Clupea harengus. J Fish Biol 45:569-588

Ganias K (2009) Linking sardine spawning dynamics to environmental variability. Estuar Coast Shelf Sci 84: 402-408

Ganias K, Somarakis S, Machias A, Theodorou AJ (2003) Evaluation of spawning frequency in a Mediterranean sardine population (Sardina pilchardus sardina). Mar Biol 142:1169-1179

Ganias K, Somarakis S, Koutsikopoulos C, Machias A (2007) Factors affecting the spawning period of sardine in two highly oligotrophic Seas. Mar Biol 151:1559-1569

Ganias K, Somarakis S, Nunes C, Stratoudakis Y (2014) Reproductive potential. In: Ganias K (ed) Biology and ecology of sardines and anchovies. CRC Press, Taylor \& Francis Group, Boca Raton, p 79-121

Garcia A, Pérez N, Lo NCH, Lago de Lanzos A, Sola A (1992) The egg production method applied to the spawning biomass estimation of sardine, Sardina pilchardus (Walb) on the North Atlantic Spanish coast. Bol Inst Esp Oceanogr 8:123-138

Garrido S, Cristóvão A, Caldeira C, Ben-Hamadou R and others (2016) Effect of temperature on the growth, survival, development and foraging behaviour of Sardina pilchardus larvae. Mar Ecol Prog Ser 559:131-145

* Gatti P, Petitgas P, Huret M (2017) Comparing biological traits of anchovy and sardine in the Bay of Biscay: a modelling approach with the dynamic energy budget. Ecol Modell 348:93-109

Giannoulaki M, Iglesias M, Tugores P, Bonanno A and others (2013) Characterising the potential habitat of European anchovy Engraulis encrasicolus in the Mediterranean Sea, at different life stages. Fish Oceanogr 22:69-89

Giannoulaki M, Schismenou E, Pyrounaki MM, Tsagarakis K (2014) Habitat characterization and migrations. In: Ganias K (ed) Biology and ecology of sardines and 
anchovies. CRC Press, Taylor \& Francis Group, Boca Raton, FL, p 191-241

Harden-Jones FR (1968) Fish migration. Edward Arnold Publishers, London

Hay DE, Brett JR (1988) Maturation and fecundity of Pacific herring (Clupea harengus pallasi): an experimental study with comparisons to natural populations. Can J Fish Aquat Sci 45:399-406

Heath MR (1992) Field investigations of the early life stages of marine fish. Adv Mar Biol 28:1-174

Hempel G (1971) Egg production and egg mortality in herring. Rapp P-V Reun Cons Int Explor Mer 160:8-11

Hewitt R (1981) The value of pattern in the distribution of young fish. Rapp P-V Reun Cons Int Explor Mer 178: 229-236

Higgs D, Fuiman LA (1996) Ontogeny of visual and mechanosensory structure and function in Atlantic menhaden Brevoortia tyrannus. J Exp Biol 199:2619-2629

Hilborn R, Amoroso RO, Bogazzi E, Jensen OP, Parma AM, Szuwalski C, Walters CJ (2017) When does fishing forage species affect their predators? Fish Res 191:211-221

Hjort J (1914) Fluctuations in the great fisheries of northern Europe, viewed in the light of biological research. Rapp P-V Reun Cons Int Explor Mer 20:1-228

Houde ED (1987) Fish life dynamics and recruitment variability. Trans Am Fish Soc 2:17-29

Houde ED (1989) Comparative growth, mortality, and energetics of marine fish larvae: temperature and implied latitudinal effects. Fish Bull 87:471-495

Houde ED (1997) Patterns and consequences of selective processes in teleost early life histories. In: Chambers RC, Trippel EA (eds) Early life history and recruitment in fish populations. Springer, Dordrecht, p 173-196

Houde ED (2009) Recruitment variability. In: Jakobsen T, Fogarty MJ, Megrey BA, Moksness E (eds) Fish reproductive biology: implications for assessment and management. Wiley-Blackwell, Oxford, p 91-171

*Hsieh C, Reiss CS, Hunter JR, Beddington JR, May RM, Sugihara G (2006) Fishing elevates variability in the abundance of exploited species. Nature 443:859-862

Hunter JR, Coyne KM (1982) The onset of schooling in northern anchovy larvae. CalCOFI Rep 23:246-251

Hunter JR, Lo NCH (1997) The daily egg production method of biomass estimation: some problems and potential improvements. Ozeanografika 2:41-69

Hunter JR, Sanchez C (1976) Diel changes in swim bladder inflation of the larvae of the northern anchovy, Engraulis mordax. Fish Bull 74:847-855

Huret M, Petitgas P, Woillez M (2010) Dispersal kernels and their drivers captured with a hydrodynamic model and spatial indices: A case study on anchovy (Engraulis encrasicolus) early life stages in the Bay of Biscay. Prog Oceanogr 87:6-17

*Huse G (2016) A spatial approach to understand herring population dynamics. Can J Fish Aquat Sci 73:177-188

ICES (1998) Report of the working group on the assessment of mackerel, horse mackerel, sardine and anchovy. ICES CM 1998/Assess 6:2

Iles TD, Sinclair M (1982) Atlantic herring: stock discreteness and abundance. Science 215:627-633

Irigoien X, Fiksen Ø, Cotano U, Uriarte A and others (2007) Could Biscay Bay anchovy recruit through a spatial loophole? Prog Oceanogr 74:132-148

Jobling M (1998) Feeding and nutrition in intensive fish farming. In: Black KD, Pickering AD C (eds) Biology of farmed fish. Sheffield Academic Press, Sheffield

Kawasaki T, Omori M (1995) Possible mechanisms underly- ing fluctuations in the Far Eastern sardine population inferred from time series of two biological traits. Fish Oceanogr 4:238-242

KKendall AW Jr, Ahlstrom EH, Moser HG (1984) Early life history stages of fishes and their characters. In: Moser HG, Richards WJ, Cohen DM, Fahay MP, Kendall AW, Richardson SL (eds) Ontogeny and systematics of fishes. American Society of Ichthyologists and Herpetologists, Spec Publ 1, Allen Press, Lawrence, KS, p 11-22

Kitchell JF, Stewart DJ, Weininger D (1977) Applications of a bioenergetics model to yellow perch (Perca flavescens) and walleye (Stizostedion vitreum vitreum). J Fish Res Board Can 34:1922-1935

KKováč V, Copp GH (1999) Prelude: looking at early development in fishes. Environ Biol Fishes 56:7-14

Lago de Lanzós A, Quintanilla L, Franco C (1998) The daily egg production method applied to the spawning biomass estimation of sardine, Sardina pilchardus off the North Atlantic Spanish coast. ICES CM 1998/BB 17:1-20

Lasker R (1978) The relation between oceanographic conditions, and larval anchovy food in the California Current: identification of factors contributing to recruitment failure. Rapp P-V Reun Cons Int Explor Mer 173:212-230

Lett C, Rose KA, Megrey BA (2009) Biophysical models of small pelagic fish. In: Checkley DM, Alheit J, Oozeki Y, Roy C (eds) Climate change and small pelagic fish. Cambridge University Press, New York, NY, p 88-111

Litvak MK, Leggett WC (1992) Age and size-selective predation on larval fishes: the bigger-is-better hypothesis revisited. Mar Ecol Prog Ser 81:13-24

* Lo NCH, Green-Ruiz YA, Jacob-Cervantes M, Moser HG, Lynn RJ (1996) Egg production and spawning biomass of Pacific sardine (Sardinops sagax) in 1994, determined by the daily egg production method. CalCOFI Rep 37:160-174

Lo NCH, Macewicz BJ, Griffith DA (2005) Spawning biomass of Pacific sardine (Sardinops sagax), from 1994-2004, off California. CalCOFI Rep 46:93-112

* Lo NCH, Macewicz BJ, Griffith DA (2010) Spawning biomass of Pacific sardine (Sardinops sagax) off the U.S. in 2010. US Dep Commer, NOAA Tech Memo, NOAA-TMNMFS-SWFSC-463

Ma Y, Kjesbu OS, Jørgensen T (1998) Effects of ration on the maturation and fecundity in captive Atlantic herring (Clupea harengus). Can J Fish Aquat Sci 55:900-908

MacCall AD (1990) Dynamic geography of marine fish populations. Washington Sea Grant/Recruitment Fisheries Oceanography, University of Washington Press, Seattle, WA

Macewicz B, Castro Gonzalez JJ, Cotero-Altamirano CE, Hunter JR (1996) Adult reproductive parameters of Pacific sardine (Sardinops sagax) during 1994. CalCOFI Rep 37:140-151

Mantzouni I, Somarakis S, Moutopoulos DK, Kallianiotis A, Koutsikopoulos C (2007) Periodic, spatially structured matrix model for the study of anchovy (Engraulis encrasicolus) population dynamics in N Aegean Sea (E. Mediterranean). Ecol Modell 208:367-377

Marshall TC (2009) Implementing information on stock reproductive potential in fisheries management: the motivation, challenges and opportunities. In: Jakobsen $\mathrm{T}$, Fogarty MJ, Megrey BA, Moksness E (eds) Fish reproductive biology: implications for assessment and management. Wiley-Blackwell, Oxford, p 395-420

McBride RS, Somarakis S, Fitzhugh GR, Albert A and others (2015) Energy acquisition and allocation to egg production in relation to fish reproductive strategies. Fish Fish 16:23-57 
Melià P, Petrillo M, Albertelli G, Mandich A, Gatto M (2012) A bootstrap approach to account for uncertainty in egg production methods applied to small fish stocks. Fish Res 117-118:130-136

Miller TJ, Crowder LB, Rice JA, Marschall EA (1988) Larval size and recruitment mechanisms in fishes: toward a conceptual framework. Can J Fish Aquat Sci 45:1657-1670

Milton DA, Blaber SJM, Rawlinson NJF (1994) Reproductive biology and egg production of three species of Clupeidae from Kiribati, tropical central Pacific. Fish Bull 92: 102-121

Milton D, Blaber SJM, Rawlinson NJF (1995) Fecundity and egg production of four species of short-lived clupeoid from Solomon Islands, tropical South Pacific. ICES J Mar Sci 52:111-125

Morello EB, Arneri E (2009) Anchovy and sardine in the Adriatic Sea: an ecological review. Oceanogr Mar Biol Annu Rev 47:209-256

* Murphy HM, Warren-Myers FW, Jenkins GP, Hamer PA, Swearer SE (2014) Variability in size-selective mortality obscures the importance of larval traits to recruitment success in a temperate marine fish. Oecologia 175: 1201-1210

Myers RA, Barrowman NJ (1996) Is fish recruitment related to spawner abundance? Fish Bull 94:707-724

*Nash RDM, Dickey-Collas M, Kell LT (2009) Stock and recruitment in North Sea herring (Clupea harengus); compensation and depensation in the population dynamics. Fish Res 95:88-97

Nielsen R, Munk P (2004) Growth pattern and growth dependent mortality of larval and pelagic juvenile North Sea cod Gadus morhua. Mar Ecol Prog Ser 278:261-270

Nikolioudakis N, Koumoundouros G, Kiparissis S, Somarakis S (2010) Defining length-at-metamorphosis in fishes: a multi-character approach. Mar Biol 157: 991-1001

Nikolioudakis N, Palomera I, Machias A, Somarakis S (2011) Diel feeding intensity and daily ration of the sardine Sardina pilchardus. Mar Ecol Prog Ser 437:215-228

Nikolioudakis N, Isari S, Somarakis S (2014a) Trophodynamics of anchovy in a non-upwelling system: direct comparison with sardine. Mar Ecol Prog Ser 500:215-229

Nikolioudakis N, Koumoundouros G, Somarakis S (2014b) Synchronization in allometric and morphological changes during metamorphosis: comparison among four sparid species. Aquat Biol 21:155-165

Nunes C, Silva A, Marques V, Ganias K (2011) Integrating fish size, condition, and population demography in the estimation of Atlantic sardine annual fecundity. Cienc Mar 37:565-584

* O'Connell CP (1981) Development of organ systems in the northern anchovy, Engraulis mordax, and other teleosts. Am Zool 21:429-446

O'Connor MI, Bruno JF, Gaines SD, Halpern BS, Lester SE, Kinlan BP, Weiss JM (2007) Temperature control of larval dispersal and the implications for marine ecology, evolution, and conservation. Proc Natl Acad Sci USA 104: 1266-1271

* Olivar MP, Salat J, Palomera I (2001) Comparative study of spatial distribution patterns of the early stages of anchovy and pilchard in the NW Mediterranean Sea. Mar Ecol Prog Ser 217:111-120

Óskarsson GJ, Taggart C (2006) Fecundity variation in Icelandic summer-spawning herring and implications for reproductive potential. ICES J Mar Sci 63:493-503

Óskarsson GJ, Kjesbu OS, Slotte A (2002) Predictions of realised fecundity and spawning time in Norwegian spring-spawning herring (Clupea harengus). J Sea Res 48:59-79

Pájaro M, Macchi GJ, Leonarduzzi E, Hansen JE (2009) Spawning biomass of Argentine anchovy (Engraulis anchoita) from 1996 to 2004 using the daily egg production method. J Mar Biol Assoc UK 89:829-837

* Palomera I, Olivar MP, Salat J, Sabatés A, Coll M, García A, Morales-Nin B (2007) Small pelagic fish in the NW Mediterranean Sea: an ecological review. Prog Oceanogr 74: 377-396

Parrish RH, Mallicoate DL, Klingbeil RA (1986) Age dependent fecundity, number of spawnings per year, sex ratio, and maturation stages in northern anchovy, Engraulis mordax. Fish Bull 84:503-517

* Peck MA, Reglero P, Takahashi M, Catalán IA (2013) Life cycle ecophysiology of small pelagic fish and climatedriven changes in populations. Prog Oceanogr 116: 220-245

* Peebles EB, Hall JR, Tolley SG (1996) Egg production by the bay anchovy Anchoa mitchilli in relation to adult and larval prey fields. Mar Ecol Prog Ser 131:61-73

* Pepin P (1991) Effect of temperature and size on development, mortality, and survival rates of the pelagic early life history stages of marine fish. Can J Fish Aquat Sci 48: 503-518

* Pepin P (2004) Early life history studies of prey-predator interactions: quantifying the stochastic individual responses to environmental variability. Can J Fish Aquat Sci 61:659-671

Pepin P (2016) Reconsidering the impossible - linking environmental drivers to growth, mortality, and recruitment of fish. Can J Fish Aquat Sci 73:205-215

* Pepin P, Shears TH, de Lafontaine Y (1992) Significance of body size to the interaction between a larval fish (Mallotus villosus) and a vertebrate predator (Gasterosteus aculeatus). Mar Ecol Prog Ser 81:1-12

* Pérez N, Figueiredo I, Macewicz B (1992) The spawning frequency of sardine, Sardina pilchardus (Walb.), off the Atlantic Iberian coast. Bol Inst Esp Oceanogr 8:175-189

* Petitgas P, Secor DH, McQuinn I, Huse G, Lo N (2010) Stock collapses and their recovery: mechanisms that establish and maintain life-cycle closure in space and time. ICES J Mar Sci 67:1841-1848

* Petitgas P, Rijnsdorp AD, Dickey-Collas M, Engelhard GH and others (2013) Impacts of climate change on the complex life cycles of fish. Fish Oceanogr 22:121-139

Picquelle SJ, Stauffer G (1985) Parameter estimation for an egg production method of anchovy biomass assessment. In: Lasker R (ed) An egg production method for estimating spawning biomass of pelagic fish: application to the Northern anchovy, Engraulis mordax. NOAA Technical Rep NMFS 36, p 7-16

* Planque B, Bellier E, Lazure P (2007) Modelling potential spawning habitat of sardine (Sardina pilchardus) and anchovy (Engraulis encrasicolus) in the Bay of Biscay. Fish Oceanogr 16:16-30

* Politikos DV, Somarakis S, Tsiaras KP, Giannoulaki M, Petihakis G, Machias A, Triantafyllou G (2015) Simulating anchovy's full life cycle in the northern Aegean Sea (eastern Mediterranean): A coupled hydro-biogeochemical-IBM model. Prog Oceanogr 138:399-416

*Pörtner HO, Farrell AP (2008) Ecology: physiology and climate change. Science 322:690-692

* Pörtner HO, Peck MA (2010) Climate change effects on fishes and fisheries: towards a cause-and-effect understanding. J Fish Biol 77:1745-1779

* Punt AE, A'mar T, Bond NA, Butterworth DS and others 
(2014) Fisheries management under climate and environmental uncertainty: control rules and performance simulation. ICES J Mar Sci 71:2208-2220

Pyper BJ, Peterman RM (1998) Comparison of methods to account for autocorrelation in correlation analyses of fish data. Can J Fish Aquat Sci 55:2127-2140

Q Quintanilla L, Pérez N (2000) Spawning frequency of sardine Sardina pilchardus (Walb.) off the Spanish North Atlantic coast in 1997. Fish Res 45:73-79

Raventos N, Macpherson E (2005) Effect of pelagic larval growth and size-at-hatching on post-settlement survivorship in two temperate labrid fish of the genus Symphodus. Mar Ecol Prog Ser 285:205-211

Ricard D, Minto C, Jensen OP, Baum JK (2012) Examining the knowledge base and status of commercially exploited marine species with the RAM Legacy Stock Assessment Database. Fish Fish 13:380-398

Ricard D, Zimmermann F, Heino M (2016) Are negative intra-specific interactions important for recruitment dynamics? A case study of Atlantic fish stocks. Mar Ecol Prog Ser 547:211-217

Ricker WE (1975) Computation and interpretation of biological statistics of fish populations. Bull Fish Res Board Can 191:1-382

Rijnsdorp AD, Peck MA, Engelhard GH, Möllmann C, Pinnegar JK (2009) Resolving the effect of climate change on fish populations. ICES J Mar Sci 66:1570-1583

Robert D, Castonguay M, Fortier L (2007) Early growth and recruitment in Atlantic mackerel Scomber scombrus: discriminating the effects of fast growth and selection for fast growth. Mar Ecol Prog Ser 337:209-219

Rosa R, Gonzalez L, Broitman B, Garrido S, Santos A, Nunes M (2010) Bioenergetics of small pelagic fishes in upwelling systems: relationship between fish condition, coastal ecosystem dynamics and fisheries. Mar Ecol Prog Ser 410:205-218

Rose KA, Cowan JH, Winemiller KO, Myers RA, Hilborn R (2001) Compensatory density dependence in fish populations: importance, controversy, understanding and prognosis. Fish Fish 2:293-327

Rose KA, Fiechter J, Curchitser EN, Hedstrom K and others (2015) Demonstration of a fully-coupled end-to-end model for small pelagic fish using sardine and anchovy in the California Current. Prog Oceanogr 138:348-380

Sabatés A, Zaragoza N, Grau C, Salat J (2008) Vertical distribution of early developmental stages in two coexisting clupeoid species, Sardinella aurita and Engraulis encrasicolus. Mar Ecol Prog Ser 364:169-180

* Santos Schmidt TCd, Slotte A, Kennedy J, Sundby S and others (2017) Oogenesis and reproductive investment of Atlantic herring are functions of not only present but long-ago environmental influences as well. Proc Natl Acad Sci USA 114:2634-2639

Schismenou E, Somarakis S, Thorsen A, Kjesbu OS (2012) Dynamics of de novo vitellogenesis in fish with indeterminate fecundity: an application of oocyte packing density theory to European anchovy, Engraulis encrasicolus. Mar Biol 159:757-768

Schismenou E, Tsiaras K, Kourepini M, Lefkaditou E, Triantafyllou G, Somarakis S (2013) Seasonal changes in growth and condition of anchovy late larvae explained with a hydrodynamic-biogeochemical model simulation. Mar Ecol Prog Ser 478:197-209

Schismenou E, Giannoulaki M, Tsiaras K, Lefkaditou E, Triantafyllou G, Somarakis S (2014) Disentangling the effects of inherent otolith growth and model-simulated ecosystem parameters on the daily growth rate of young anchovies. Mar Ecol Prog Ser 515:227-237

* Schismenou E, Palmer M, Giannoulaki M, Alvarez I, Tsiaras K, Triantafyllou G, Somarakis S (2016) Seasonal changes in otolith increment width trajectories and the effect of temperature on the daily growth rate of young sardines. Fish Oceanogr 25:362-372

Schwartzlose RA, Alheit J, Bakun A, Baumgartner TR and others (1999) Worldwide large-scale fluctuations of sardine and anchovy populations. S Afr J Mar Sci 21: 289-347

Searcy SP, Sponaugle S (2001) Selective mortality during the larval-juvenile transition in two coral reef fishes. Ecology 82:2452-2470

Shelton PA, Armstrong MJ, Roel BA (1993) An overview of the application of the daily egg production method in the assessment and management of anchovy in the southeast Atlantic. Bull Mar Sci 53:778-794

Silva A, Santos M, Caneco B, Pestana G, Porteiro C, Carrera P, Stratoudakis Y (2006) Temporal and geographic variability of sardine maturity at length in the northeastern Atlantic and the western Mediterranean. ICES J Mar Sci 63:663-676

Sinclair M (1988) Marine populations: an essay on population regulation and speciation. Washington Sea Grant Program, University of Washington Press, Seattle, WA

Slotte A, Johannessen A, Kjesbu OS (2000) Effects of fish size on spawning time in Norwegian spring-spawning herring. J Fish Biol 56:295-310

* Smith PE (1985) Year-class strength and survival of 0-group clupeoids. Can J Fish Aquat Sci 42:S69-S82

* Solemdal P (1997) Maternal effects - a link between the past and the future. J Sea Res 37:213-227

Somarakis S (1999) Ichthyoplankton of the Northeastern Aegean Sea with emphasis on anchovy, Engraulis encrasicolus (Linnaeus, 1758) (June 1993, 1994, 1995, 1996). PhD Thesis, University of Crete, Heraklion

Somarakis S (2005) Marked interannual differences in reproductive parameters and daily egg production of anchovy in the northern Aegean Sea. Belg J Zool 135: $247-252$

Somarakis S, Nikolioudakis N (2007) Oceanographic habitat, growth and mortality of larval anchovy (Engraulis encrasicolus) in the northern Aegean Sea (eastern Mediterranean). Mar Biol 152:1143-1158

Somarakis S, Nikolioudakis N (2010) What makes a late anchovy larva? The development of the caudal fin seen as a milestone in fish ontogeny. J Plankton Res 32:317-326

Somarakis S, Catalano B, Tsimenides N (1998) Catchability and retention of larval European anchovy, Engraulis encrasicolus, with bongo nets. Fish Bull 96:917-925

* Somarakis S, Koutsikopoulos C, Machias A, Tsimenides N (2002) Applying the daily egg production method (DEPM) to small stocks in highly heterogeneous seas. Fish Res 55:193-204

Somarakis S, Palomera I, Garcia A, Quintanilla L, Koutsikopoulos C, Uriarte A, Motos L (2004) Daily egg production of anchovy in European waters. ICES J Mar Sci 61:944-958

Somarakis S, Ganias K, Siapatis A, Koutsikopoulos C, Machias A, Papaconstantinou C (2006a) Spawning habitat and daily egg production of sardine in the eastern Mediterranean. Fish Oceanogr 15:281-292

Somarakis S, Tsianis DE, Machias A, Stergiou KI (2006b) An overview of biological data related to anchovy and sardine stocks in Greek waters. In: Palomares MLD, Stergiou KI, Pauly D (eds) Fishes in databases and ecosystems. Fisheries Centre Research Reports, University of 
British Columbia, Vancouver, p 56-64

Somarakis S, Ramfos A, Palialexis A, Valavanis VD (2011) Contrasting multispecies patterns in larval fish production trace inter-annual variability in oceanographic conditions over the N.E. Aegean Sea continental shelf (Eastern Mediterranean). Hydrobiologia 670:275-287

Somarakis S, Schismenou E, Siapatis A, Giannoulaki M, Kallianiotis A, Machias A (2012) High variability in the daily egg production method parameters of an eastern Mediterranean anchovy stock: Influence of environmental factors, fish condition and population density. Fish Res 117-118:12-21

Sponaugle S (2010) Otolith microstructure reveals ecological and oceanographic processes important to ecosystem-based management. Environ Biol Fishes 89:221-238

Stergiou KI, Somarakis S, Triantafyllou G, Tsiaras KP and others (2016) Trends in productivity and biomass yields in the Mediterranean Sea Large Marine Ecosystem during climate change. Environ Dev 17:57-74

Szuwalski CS, Vert-Pre KA, Punt AE, Branch TA, Hilborn R (2015) Examining common assumptions about recruitment: a meta-analysis of recruitment dynamics for worldwide marine fisheries. Fish Fish 16:633-648

Takasuka A, Aoki I, Mitani I (2003) Evidence of growthselective predation on larval Japanese anchovy Engraulis japonicus in Sagami Bay. Mar Ecol Prog Ser 252: 223-238

Takasuka A, Oozeki Y, Kimura R, Kubota H, Aoki I (2004) Growth-selective predation hypothesis revisited for larval anchovy in offshore waters: cannibalism by juveniles versus predation by skipjack tunas. Mar Ecol Prog Ser 278:297-302

Takasuka A, Oozeki Y, Kubota H, Tsuruta Y, Funamoto T (2005) Temperature impacts on reproductive parameters for Japanese anchovy: comparison between inshore and offshore waters. Fish Res 76:475-482

Takasuka A, Aoki I, Oozeki Y (2007a) Predator-specific growth-selective predation on larval Japanese anchovy Engraulis japonicus. Mar Ecol Prog Ser 350:99-107

Takasuka A, Oozeki Y, Aoki I (2007b) Optimal growth temperature hypothesis: Why do anchovy flourish and sardine collapse or vice versa under the same ocean regime? Can J Fish Aquat Sci 64:768-776

Takasuka A, Sakai A, Aoki I (2017) Dynamics of growthbased survival mechanisms in Japanese anchovy (Engraulis japonicus) larvae. Can J Fish Aquat Sci 74:812-823

* Tanaka Y, Satoh K, Iwahashi M, Yamada H (2006) Growthdependent recruitment of Pacific bluefin tuna Thunnus orientalis in the northwestern Pacific Ocean. Mar Ecol Prog Ser 319:225-235

*Thorrold SR, Williams DM (1989) Analysis of otolith microstructure to determine growth histories in larval cohorts of a tropical herring (Herklotsichthys castelnaui). Can J Fish Aquat Sci 46:1615-1624

Townsend DW (1992) Ecology of larval herring in relation to the oceanography of the Gulf of Maine. J Plankton Res $14: 467-493$

Editorial responsibility: Dominique Robert (Guest Editor), St. John's, Newfoundland, Canada
Trippel EA (1999) Estimation of stock reproductive potential: history and challenges for Canadian Atlantic gadoid stock assessments. J Northwest Atl Fish Sci 25:61-82

*Uotani I (1973) Diurnal changes of gas bladder and behavior of postlarval anchovy and other related species. Bull Jpn Soc Sci Fish 39:867-876

* Uriarte A, Alday A, Santos M, Motos L (2012) A re-evaluation of the spawning fraction estimation procedures for Bay of Biscay anchovy, a species with short interspawning intervals. Fish Res 117-118:96-111

van der Lingen CD, Huggett JA (2003) The role of ichthyoplankton surveys in recruitment research and management of South African anchovy and sardine. In: Browman HL, Skiftesvik AB (eds) The Big Fish Bang. Proceedings of the 26th Annual Larval Fish Conference, Institute of Marine Research, Bergen, p 303-343

*Vasconcellos MC, Freire KF, Castello JP, Castello JP (1998) Distribution patterns and feeding success of anchovy, Engraulis anchoita, larvae off southern Brazil. Sci Mar 62:385-392

*Vigliola L, Meekan MG (2002) Size at hatching and planktonic growth determine post-settlement survivorship of a coral reef fish. Oecologia 131:89-93

Ward T, Hoedt F, McLeay L, Dimmlich WF and others (2001) Effects of the 1995 and 1998 mass mortality events on the spawning biomass of sardine, Sardinops sagax, in South Australian waters. ICES J Mar Sci 58:865-875

Watanabe Y (2002) Resurgence and decline of the Japanese sardine population. In: Fuiman LA, Werner RG (eds) Fishery science: the unique contributions of early life stages. Blackwell Publishing, Oxford, p 243-257

*Webb PW, Weihs D (1986) Functional locomotor morphology of early life-history stages of fishes. Trans Am Fish Soc 115:115-127

Werner FE, Quinlan JA, Blanton BO, Luettich RA Jr (1997) The role of hydrodynamics in explaining variability in fish populations. J Sea Res 37:195-212

*Winters G, Wheeler JP (1996) Environmental and phenotypic factors affecting the reproductive cycle of Atlantic herring. ICES J Mar Sci 53:73-88

*Wright PJ (1992) Ovarian development, spawning frequency and batch fecundity in Encrasicholina heteroloba (Ruppell, 1858). J Fish Biol 40:833-844

Wright PJ, Trippel EA (2009) Fishery-induced demographic changes in the timing of spawning: consequences for reproductive success. Fish Fish 10:283-304

* Xu Y, Rose KA, Chai F, Chavez FP, Ayón P (2015) Does spatial variation in environmental conditions affect recruitment? A study using a 3-D model of Peruvian anchovy. Prog Oceanogr 138:417-430

Kuwolinski JP, Demer DA (2012) A cold oceanographic regime with high exploitation rates in the Northeast Pacific forecasts a collapse of the sardine stock. Proc Natl Acad Sci USA 109:4175-4180

Zwolinski JP, Demer DA (2014) Environmental and parental control of Pacific sardine (Sardinops sagax) recruitment. ICES J Mar Sci 71:2198-2207

Submitted: September 14, 2017; Accepted: May 17, 2018

Proofs received from author(s): June 25, 2018 